\title{
Pharmacological rescue of Ras signaling, GluA1-dependent synaptic plasticity, and learning deficits in a fragile $X$ model
}

\author{
Chae-Seok Lim, ${ }^{1}$ Elizabeth T. Hoang, ${ }^{1,2}$ Kenneth E. Viar, ${ }^{1}$ Ruth L. Stornetta, ${ }^{1}$ Michael $M$. Scott, ${ }^{1}$ \\ and J. Julius $\mathrm{Zhu}^{1,3,4}$ \\ ${ }^{1}$ Department of Pharmacology, ${ }^{2}$ Department of Psychology, ${ }^{3}$ Department of Neuroscience, University of Virginia School of \\ Medicine, University of Virginia College of Arts and Sciences, Charlottesville, Virginia 22908, USA
}

\begin{abstract}
Fragile $\mathrm{X}$ syndrome, caused by the loss of Fmr1 gene function, is the most common form of inherited mental retardation, with no effective treatment. Using a tractable animal model, we investigated mechanisms of action of a few FDA-approved psychoactive drugs that modestly benefit the cognitive performance in fragile $X$ patients. Here we report that compounds activating serotonin $(5 \mathrm{HT})$ subtype $2 \mathrm{~B}$ receptors $\left(5 \mathrm{HT} \mathrm{T}_{2 \mathrm{~B}}-\mathrm{Rs}\right.$ ) or dopamine (DA) subtype 1-like receptors $\left(\mathrm{D}_{1}-\mathrm{Rs}\right)$ and/or those inhibiting $5 \mathrm{HT}_{2 \mathrm{~A}}-\mathrm{Rs}$ or $\mathrm{D}_{2}$-Rs moderately enhance Ras-PI3K/PKB signaling input, GluA1-dependent synaptic plasticity, and learning in Fmr1 knockout mice. Unexpectedly, combinations of these 5HT and DA compounds at low doses synergistically stimulate Ras-PI3K/PKB signal transduction and GluA1-dependent synaptic plasticity and remarkably restore normal learning in Fmr1 knockout mice without causing anxiety-related side effects. These findings suggest that properly dosed and combined FDAapproved psychoactive drugs may effectively treat the cognitive impairment associated with fragile $\mathbf{X}$ syndrome.
\end{abstract}

[Keywords: autism; AMPA receptor trafficking; Ras-PI3K signaling; mental retardation; cocktail drug treatment] Supplemental material is available for this article.

Received October 8, 2013; revised version accepted December 27, 2013.

Fragile X syndrome, the most common form of inherited mental impairment, is caused by the loss of function of the fragile $\mathrm{X}$ mental retardation protein (FMRP), coded by gene Fmr1 (Bagni and Greenough 2005; Levenga et al. 2010). Fragile X patients have cognitive impairment that is particularly pronounced in active, high-level associative learning (Maes et al. 1994; Frankland et al. 2004; Lanfranchi et al. 2009). Consistent with clinical observations, Fmr1 knockout mice, an animal model for fragile $\mathrm{X}$ syndrome (The Dutch-Belgian Fragile X Consortium 1994), exhibit impaired associative learning but show no defects in spatial learning (Paradee et al. 1999; Van Dam et al. 2000; Zhao et al. 2005; Hayashi et al. 2007; Guo et al. 2011), behaviorally phenocopying PI3K signaling-inhibited rats (Lin et al. 2001; Chen et al. 2005; Horwood et al. 2006) and GluA1 knockout mice (Zamanillo et al. 1999; Schmitt et al. 2004, 2005).

Recent fragile X research has shown that NMDA-Rdependent long-term depression is unchanged, but mGluRdependent long-term depression is modestly up-regulated in Fmr1 knockout mice (Levenga et al. 2010; Bhakar et al. 2012). The exaggerated mGluR signaling seems responsible

${ }^{4}$ Corresponding author

E-mail jizhu@virginia.edu

Article is online at http://www.genesdev.org/cgi/doi/10.1101/gad.232470.113. for a few phenotypes of the fragile X mouse model, including the altered ocular dominance plasticity, audiogenic-induced seizures, and disproportionate passive avoidance extinction (Bhakar et al. 2012). In addition, NMDA-R-dependent longterm potentiation (LTP) is significantly reduced in Fmr1 knockout mice (Zhao et al. 2005; Meredith et al. 2007; Hu et al. 2008; Shang et al. 2009; Seese et al. 2012) due to a selective impairment of signal transduction between Ras and $\mathrm{PI} 3 \mathrm{~K} / \mathrm{PKB}$ that impairs GluA1-dependent (but not GluA2L- and GluA4-dependent) plasticity in Fmr1 knockout mice (Hu et al. 2008). These results raise the intriguing possibility that restoring the normal GluA1-dependent synaptic plasticity may reverse the prominent learning deficits associated with fragile $\mathrm{X}$ syndrome.

There is currently no effective treatment for fragile $\mathrm{X}$ syndrome. Because developing a new drug takes $\sim 8-$ 15 years (>13 years for neurological disorders) and costs $\sim \$ 800$ million-\$1800 million (Adams and Brantner 2010; Paul et al. 2010), any effective treatment for fragile $\mathrm{X}$

(c) 2014 Lim et al. This article is distributed exclusively by Cold Spring Harbor Laboratory Press for the first six months after the full-issue publication date (see http://genesdev.cshlp.org/site/misc/terms.xhtml). After six months, it is available under a Creative Commons License (Attribution-NonCommercial 3.0 Unported), as described at http:// creativecommons.org/licenses/by-nc/3.0/. 
seems still years away. This situation has driven desperate parents and clinicians to make off-label use of many FDA-approved psychoactive drugs that modulate serotonin (5-hydroxytryptamine [5HT]) and/or dopamine [4-(2-aminoethyl)benzene-1,2-diol (DA)] signaling, and, fortuitously, they have seen a few of these drugs having moderate beneficial effects on the cognitive performance of fragile X patients (Hagerman et al. 2009; Tranfaglia 2011; Gross et al. 2012). Unfortunately, the unknown mechanism of 5HT or DA drug action and frequent side effects have precluded clinical screening or testing of more effective $5 \mathrm{HT}$ and/or DA drug treatments. To understand the mechanisms of action of these classes of drugs, we investigated the effects of several $5 \mathrm{HT}$ and DA compounds on synaptic plasticity in Fmr1 knockout mice. We found that compounds selectively activating $5 \mathrm{HT}$ subtype $2 \mathrm{~B}$ receptors $\left(5 \mathrm{HT}_{2 \mathrm{~B}}-\mathrm{Rs}\right)$ or DA subtype 1-like receptors $\left(\mathrm{D}_{1}\right.$-Rs) and/or inhibiting $5 \mathrm{HT}_{2 \mathrm{~A}}$-Rs or $\mathrm{D}_{2}$-Rs moderately enhanced Ras-PI3K/PKB signaling input, GluA1-dependent synaptic plasticity, and learning in Fmr1 knockout mice. Combinations of these 5HT and DA compounds at about their half-maximal effective doses induced an unexpected synergistic effect that boosted Ras-PI3K/PKB signal transduction, rescued GluA1-dependent synaptic plasticity, and restored normal learning in Fmr1 knockout mice without causing anxiety-related side effects. Our findings suggest that properly dosed FDA-approved psychoactive drug cocktails may effectively treat the cognitive impairment associated with fragile $\mathrm{X}$ syndrome.

\section{Results}

A few psychoactive drugs-including sertraline and nefazodone, which modulate 5HT-Rs; aripiprazole and buspirone, which modulate D-Rs; and amphetamine, which modulates both 5HT and DA-are commonly prescribed as off-label treatments for fragile X. To understand the mechanisms of action of these drugs, we investigated the effects of $5 \mathrm{HT}$ and/or DA compounds on synaptic plasticity and learning in Fmr1 knockout mice.

\section{$5 H T_{2 B}$-Rs enhance and $5 H T_{2 A}-R s$ inhibit synaptic GluA1 delivery in Fmrl knockout mice}

We first examined the effects of $5 \mathrm{HT}$ and DA compounds on synaptic plasticity in Fmr1 knockout mice using a hippocampal cultured slice preparation (Fig. 1A; see the Materials and Methods). We monitored the GluA1dependent plasticity by expressing the GFP-tagged GluA1 (GluA1-GFP), which is an "electrophysiologically tagged" or rectified channel (Hayashi et al. 2000), in CAl neurons of wild-type and Fmr1 knockout mice. Spontaneous synaptic activity in cultured slices does not drive GluA1containing AMPA-Rs into synapses but does so in the presence of histamine (Qin et al. 2005; McCormack et al. 2006; Kessels and Malinow 2009); thus, histamine was included in all in vitro trafficking experiments. As with the previous report (Hu et al. 2008), we found that GluAl-GFPexpressing neurons of wild-type mice, but not Fmr1 knockout mice, had enhanced rectification (by $\sim 35 \%$ ) of AMPA responses compared with nearby control nonexpressing neurons (Supplemental Fig. S1), indicating synaptic delivery of rectified GluA1-GFP in wild-type neurons but not Fmr1 knockout neurons. To confirm the synaptic delivery of endogenous GluA1, we expressed in CA1 neurons the GFP-tagged cytoplasmic termini of GluA1 (GluAlct-GFP) that functions as a dominant-negative construct and can selectively block synaptic trafficking of endogenous GluA1-containing AMPA-Rs (Qin et al. 2005; Kielland et al. 2009). GluA1ct-GFP-expressing neurons of wild-type mice, but not Fmr1 knockout mice, had depressed AMPA responses (Supplemental Fig. S1). Together, these results confirmed that synaptic GluAl delivery is impaired in Fmr1 knockout mice.

We then studied whether 5HT compounds enhance GluA1-dependent synaptic plasticity in Fmr1 knockout mice, since all $5 \mathrm{HT}_{2}$-Rs, including $5 \mathrm{HT}_{2 \mathrm{~A}}-\mathrm{Rs}, 5 \mathrm{HT}_{2 \mathrm{~B}}-\mathrm{Rs}$, and $5 \mathrm{HT}_{2 \mathrm{C}}-\mathrm{Rs}$, can regulate synaptic plasticity (Jacobs and Azmitia 1992; Gaspar et al. 2003; Zhong et al. 2008). In particular, $5 \mathrm{HT}_{2 \mathrm{~B}}$-Rs may stimulate PI3K/PKB signaling (Gaspar et al. 2003), which is crucial for synaptic GluA1 delivery (Man et al. 2003; Qin et al. 2005). We found that in

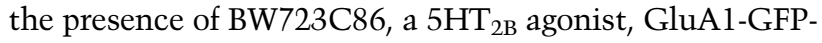
expressing neurons had enhanced rectification (by $\sim 20 \%$ ) of AMPA responses compared with nearby control nonexpressing neurons of Fmr1 knockout mice (Fig. 1B), indicating synaptic delivery of rectified GluA1-GFP. In addition, GluA1-GFP-expressing and nearby nonexpressing neurons had the same amplitude of AMPA responses (Fig. 1B), suggesting synaptic delivery of the same amount of endogenous $\mathrm{GluA} \mathrm{A}$ in nonexpressing neurons. In addition, in the presence of BW723C86, GluAlct-GFP-expressing neurons had depressed AMPA responses but the same NMDA responses compared with nearby control nonexpressing neurons (Fig. 1B), suggesting a postsynaptic blockade of synaptic delivery of endogenous GluA1. Collectively, these results suggest that $5 \mathrm{HT}_{2 \mathrm{~B}}$-Rs stimulate synaptic GluA1 delivery in Fmr1 knockout mice.

To test whether $5 \mathrm{HT}_{2 \mathrm{C}}$-Rs stimulate synaptic GluAl delivery in Fmr1 knockout mice, we included MK-212, a $5 \mathrm{HT}_{2 \mathrm{C}}$ agonist, along with histamine in culture medium during expression of GluA1-GFP in CA1 neurons. In the presence of MK-212, GluA1-GFP-expressing neurons had the same amplitude and rectification of AMPA responses as nearby nonexpressing neurons of $F m r 1$ knockout mice (Supplemental Fig. S2A), suggesting no synaptic GluA1GFP delivery. To determine whether $5 \mathrm{HT}_{2 \mathrm{C}}$-Rs inhibit synaptic GluA1 incorporation in Fmr1 knockout mice, we included MK-212 and BW723C86 along with histamine in culture medium during the expression of GluA1GFP in CA1 neurons. Neurons expressing GluA1-GFP had the same amplitude but enhanced rectification (by $\sim 15 \%$ ) of AMPA responses compared with nearby nonexpressing neurons (Supplemental Fig. S2A), indicating synaptic delivery of GluA1-GFP. These results suggest that $5 \mathrm{HT}_{2 \mathrm{C}}$-Rs do not affect synaptic GluAl delivery in Fmr1 knockout mice.

We next included $\alpha \mathrm{Me}-5 \mathrm{HT}$, a pan $5 \mathrm{HT}_{2}-\mathrm{R}$ agonist that activates $5 \mathrm{HT}_{2 \mathrm{~A}}-\mathrm{Rs}, 5 \mathrm{HT}_{2 \mathrm{~B}}-\mathrm{Rs}$, and $5 \mathrm{HT}_{2 \mathrm{C}}-\mathrm{Rs}$, in culture medium during the expression of GluA1-GFP in CA1 
A
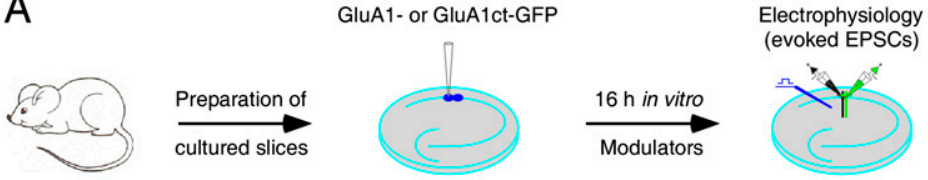

B

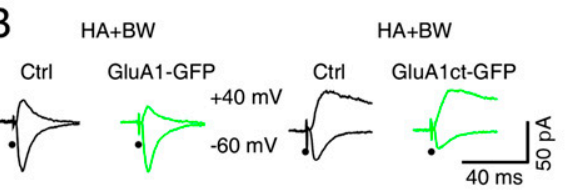

C $\mathrm{HA}+\alpha \mathrm{Me}-5 \mathrm{HT}$<smiles>CC1CCCC1</smiles>

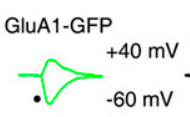

$\mathrm{HA}+\alpha \mathrm{Me}-5 \mathrm{HT}+\mathrm{MDL}$ $H A+\alpha M e-5 H T+M D L$

Ctrl GluA1-GFP
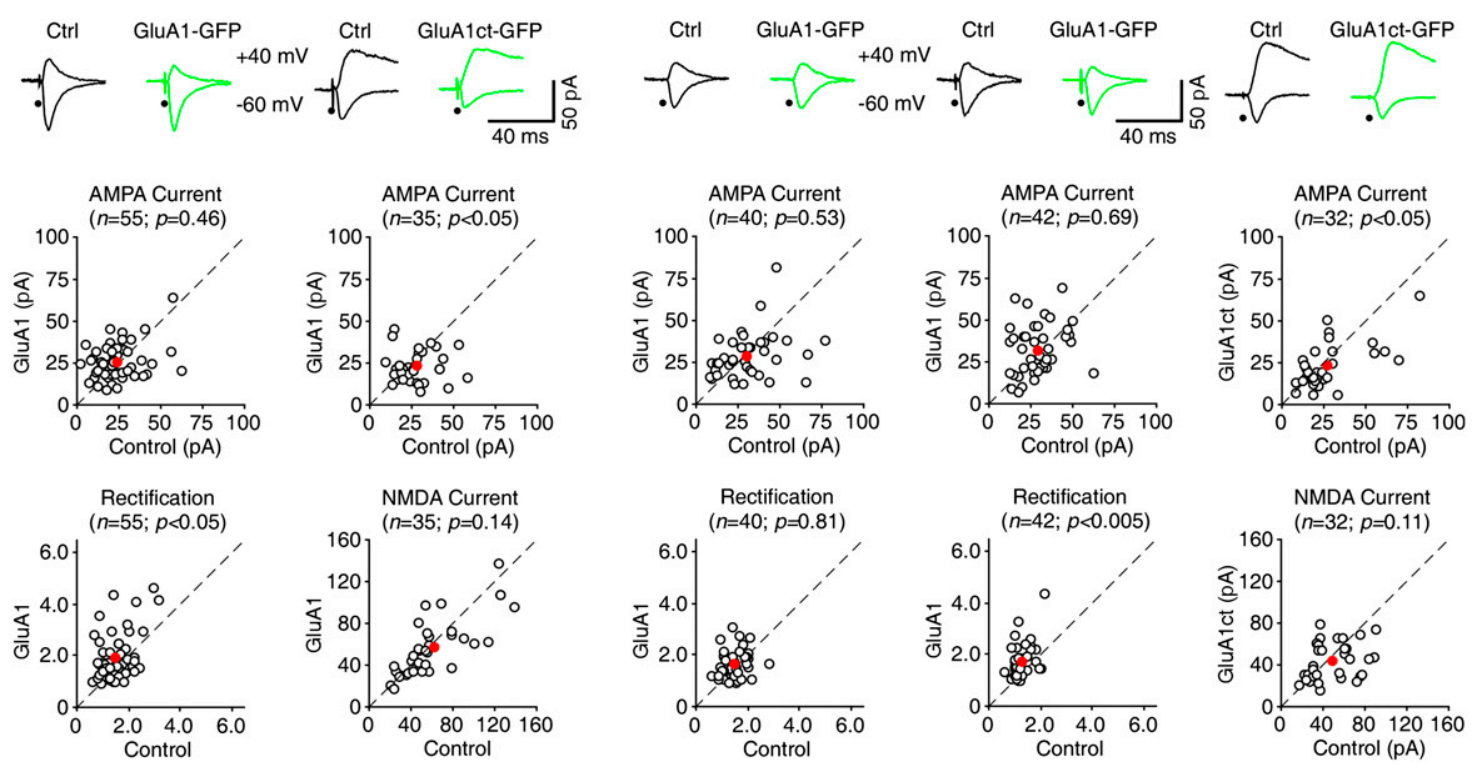

Figure 1. $5 \mathrm{HT}_{2 \mathrm{~B}}$-Rs stimulate and $5 \mathrm{HT}_{2 \mathrm{C}}-\mathrm{Rs}$ inhibit synaptic GluAl trafficking in $F m r 1$ knockout $(\mathrm{KO})$ mice. $(A)$ Schematic drawing outlines the in vitro experimental design. $(B, t o p)$ Evoked AMPA-R-mediated $(-60 \mathrm{mV})$ or AMPA-R-mediated $(-60 \mathrm{mV})$ and NMDA-Rmediated $(+40 \mathrm{mV})$ responses recorded from GluAl-GFP- or GluAlct-GFP-expressing and neighboring nonexpressing (Ctrl) neurons from Fmr1 knockout mice cultured in medium containing $75 \mu \mathrm{M}$ histamine (HA) and additional $1 \mu \mathrm{M}$ BW723C86. (Bottom) Amplitudes (ctrl: $-25.8 \pm 1.7 \mathrm{pA}$; exp: $-26.4 \pm 1.4 \mathrm{pA} ; n=55 ; P=0.46$ ) and rectifications (ctrl: $1.65 \pm 0.08 ; \exp : 1.94 \pm 0.13 ; n=55 ; P<$ 0.05) of synaptic AMPA responses in GluA1-GFP-expressing neurons and amplitudes of synaptic AMPA (ctrl: $-29.8 \pm 2.0$ pA; exp: $-23.4 \pm 1.5 \mathrm{pA} ; n=35 ; P<0.05$ ) and NMDA (ctrl: $64.6 \pm 5.5 \mathrm{pA}$; exp: $58.6 \pm 4.8 \mathrm{pA} ; n=35 ; P=0.14$ ) responses in GluAlct-GFPexpressing neurons are plotted against those obtained from nonexpressing neurons. $(C$, top) Evoked AMPA-R-mediated (-60 mV) responses recorded from GluA1-GFP-expressing or GluAlct-GFP and neighboring nonexpressing (Ctrl) neurons from Fmr1 knockout mice cultured in medium containing $75 \mu \mathrm{M}$ histamine (HA) and additional $10 \mu \mathrm{M} \alpha \mathrm{Me}-5 \mathrm{HT}$ or $10 \mu \mathrm{M} \alpha \mathrm{Me}-5 \mathrm{HT}$ and $1 \mu \mathrm{M}$ MDL11939. (Bottom) Amplitudes (ctrl: $-32.2 \pm 2.7$ pA; exp: $-29.0 \pm 2.0$ pA; $n=40 ; P=0.53$ ) and rectifications (ctrl: $1.64 \pm 0.07$; exp: 1.68 \pm 0.29 ; $n=40 ; P=0.81$ ) of synaptic AMPA responses in GluA1-GFP-expressing neurons cultured in medium with $10 \mu \mathrm{M} \alpha \mathrm{Me}-5 \mathrm{HT}$, amplitudes (ctrl: $-31.1 \pm 1.8$ pA; exp: $-32.4 \pm 2.3$ pA; $n=42 ; P=0.69$ ) and rectifications (ctrl: $1.40 \pm 0.05$; exp: $1.75 \pm 0.10 ; n=42 ; P<0.005$ ) of synaptic AMPA responses in GluA1-GFP-expressing neurons cultured in medium with $10 \mu \mathrm{M} \alpha \mathrm{Me}-5 \mathrm{HT}$ and $1 \mu \mathrm{M}$ MDL11939, and amplitudes of synaptic AMPA (ctrl: $-29.4 \pm 3.2$ pA; exp: $-23.5 \pm 3.4$ pA; $n=32 ; P<0.05$ ) and NMDA (ctrl: $51.9 \pm 4.8$ pA; exp: $44.5 \pm$ $3.2 \mathrm{pA} ; n=32 ; P=0.09$ ) responses in GluAlct-GFP-expressing neurons cultured in medium with $10 \mu \mathrm{M} \alpha \mathrm{Me}-5 \mathrm{HT}$ and $1 \mu \mathrm{M}$ MDL11939 are plotted against those obtained from nonexpressing neurons. The red dots indicate the averages, and scale bars apply to all recording traces. Statistical significances were determined with Wilcoxon tests.

neurons of Fmr1 knockout mice. In the presence of $\alpha \mathrm{Me}$ 5HT and histamine, neurons expressing GluA1-GFP had the same amplitude and rectification of AMPA responses as nearby nonexpressing neurons (Fig. 1C). These results suggest that $5 \mathrm{HT}_{2 \mathrm{~A}}$-Rs block $5 \mathrm{HT}_{2 \mathrm{~B}}$-R-stimulated synaptic delivery of GluA1 in Fmr1 knockout mice. To confirm this idea, we included $\alpha \mathrm{Me}-5 \mathrm{HT}$ and MDL11939, a $5 \mathrm{HT}_{2 \mathrm{~A}}$ antagonist, along with histamine in culture medium during the expression of GluA1-GFP in CA1 neurons of Fmr1 knockout mice. In the presence of both $\alpha \mathrm{Me}-5 \mathrm{HT}$ and MDL11939, neurons expressing GluA1-GFP had the same amplitude but enhanced rectification (by $\sim 20 \%$ ) of AMPA responses compared with nearby nonexpressing neurons (Fig. 1C), indicating synaptic delivery of GluA1-GFP and
GluA1 in expressing and nonexpressing neurons of Fmr1 knockout mice. In addition, in the presence of both $\alpha \mathrm{Me}$ 5HT and MDL11939, GluAlct-GFP-expressing neurons had depressed AMPA responses and unaltered NMDA responses compared with nearby nonexpressing neurons (Fig. 1C), confirming the synaptic delivery of endogenous GluA1. Finally, we included BW723C86 and TCB-2, a $5 \mathrm{HT}_{2 \mathrm{~A}}-\mathrm{R}$ agonist, along with histamine in culture medium during the expression of GluA1-GFP in CA1 neurons. In the presence of TCB-2 and BW7323C86, neurons expressing GluA1-GFP had the same amplitude and rectification of AMPA responses compared with nearby nonexpressing neurons (Supplemental Fig. S2B), indicating no synaptic delivery of GluA1-GFP. Collectively, these results suggest 
that $5 \mathrm{HT}_{2 \mathrm{~B}}$-Rs stimulate, $5 \mathrm{HT}_{2 \mathrm{C}}$-Rs have no effect on, and $5 \mathrm{HT}_{2 \mathrm{~A}}$-Rs inhibit synaptic delivery of GluAl-containing AMPA-Rs in Fmr1 knockout mice.

\section{$D_{1}$-Rs enhance and $D_{2}$-Rs inhibit synaptic GluA1 delivery in Fmr1 knockout mice}

We then examined whether DA compounds enhance synaptic plasticity in Fmr1 knockout mice. Both classes of DA receptors $\left(D_{1}-\mathrm{Rs}\right.$, which include DA-R subtypes 1 and 5 , and $\mathrm{D}_{2}$-Rs, which include DA-R subtypes 2,3 , and 4) regulate synaptic plasticity. In particular, $\mathrm{D}_{1}$-Rs enhance LTP and/or inhibit depotentiation (Otmakhova and Lisman 1998; Gurden et al. 2000; Li et al. 2003; Chen et al. 2004), whereas $\mathrm{D}_{2}$-Rs inhibit LTP and/or enhance depotentiation (Li et al. 2007; Kwon et al. 2008). We expressed GluA1-GFP in CA1 neurons of Fmr1 knockout mice cultured with medium containing histamine and SKF81297, a $\mathrm{D}_{1}$ agonist. In the presence of SKF81297, GluA1-GFP-expressing neurons had enhanced rectification (by $\sim 15 \%$ ) of AMPA responses compared with nearby control nonexpressing neurons of Fmr1 knockout mice (Fig. 2A), indicating synaptic delivery of GluA1-GFP. In addition, the amplitudes of AMPA responses in GluA1-GFP-expressing and nearby nonexpressing neurons were the same (Fig. 2A), suggesting synaptic delivery of the same amount of endogenous GluA1 in nonexpressing neurons. To confirm that $\mathrm{D}_{1}$-Rs stimulate synaptic delivery of endogenous GluA1 in Fmr1 knockout mice, we expressed GluA1ct-GFP in CA1 neurons. In the presence of SKF81297, GluA1ct-GFPexpressing neurons had depressed AMPA responses but the same NMDA responses compared with nearby control nonexpressing neurons (Fig. 2A), suggesting a postsynaptic blockade of synaptic delivery of endogenous GluA1. These results suggest that $\mathrm{D}_{1}$-Rs stimulate synaptic GluA1 delivery in Fmr1 knockout mice.

To test whether $\mathrm{D}_{2}$-Rs affect synaptic GluA1 delivery in Fmr1 knockout mice, we included quinpirole, a $\mathrm{D}_{2}$ agonist, along with histamine in culture medium. In the presence of quinpirole, GluA1-GFP-expressing and nearby nonexpressing neurons of Fmr1 knockout mice had the same AMPA responses (Fig. 2B), suggesting no synaptic GluA1 delivery. To determine whether $\mathrm{D}_{2}$-Rs inhibit synaptic GluA1 incorporation, we included both SKF81297 and quinpirole with histamine in culture medium. Neurons expressing GluA1-GFP had the same AMPA responses compared with nearby nonexpressing neurons (Fig. 2B), suggesting that $D_{2}-R$ activation blocked $D_{1}$-R-stimulated synaptic incorporation of GluA1. Collectively, these results suggest that $\mathrm{D}_{1}$-Rs stimulate synaptic GluA1 delivery, whereas $\mathrm{D}_{2}$-Rs inhibit synaptic GluA1 delivery.

\section{HT and DA drug cocktail restores normal synaptic GluA1 delivery in Fmr1 knockout mice}

To determine the maximal effects of 5HT and DA compounds on synaptic GluA1 delivery, we measured the dose response curves for the respective drugs. We first cultured GluA1-GFP-expressing Fmr1 knockout neurons in media with varied concentrations of BW723C86 and subsequently measured its effects on synaptic GluA1 delivery. Increasing the concentration of BW723C86 from $5 \mathrm{nM}$ to $5 \mu \mathrm{M}$ increased the relative rectification of AMPA responses in GluA1-GFP-expressing neurons compared with
A

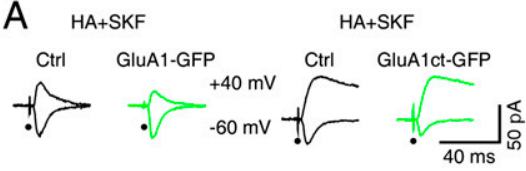

B
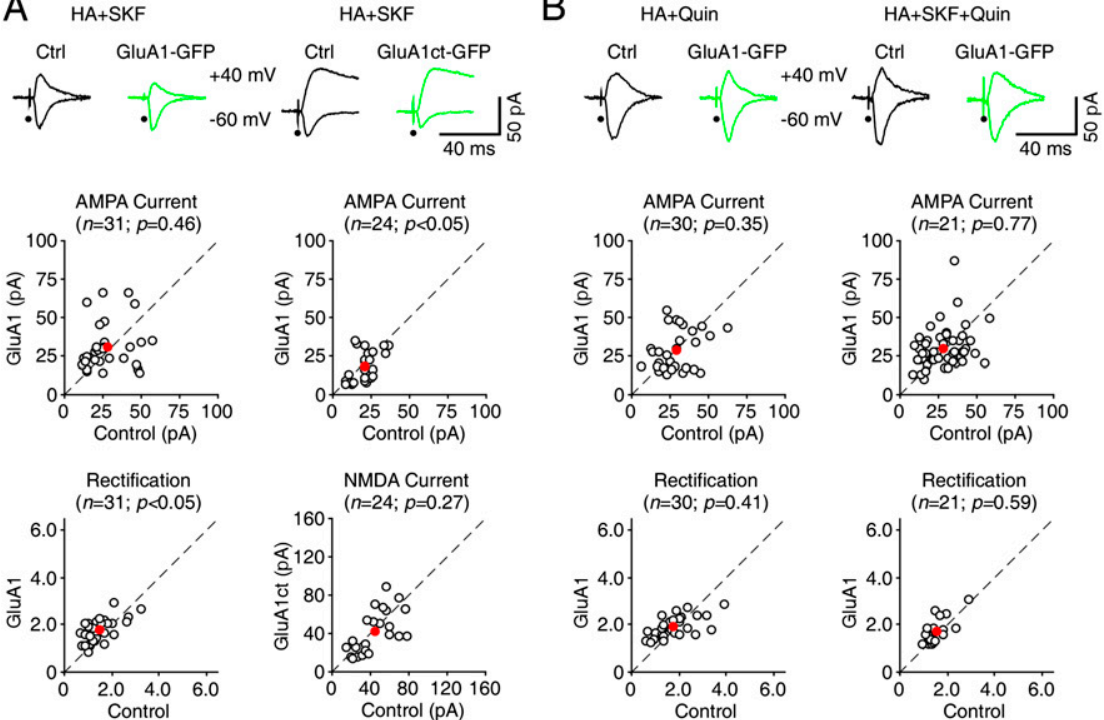

Figure 2. $\mathrm{D}_{1}$-Rs stimulate and $\mathrm{D}_{2}$-Rs inhibit synaptic GluA1 trafficking in Fmr1 knockout (KO) mice. $(A$, top) Evoked AMPA-Rmediated $(-60 \mathrm{mV})$ or AMPA-R-mediated $(-60 \mathrm{mV})$ and NMDA-R-mediated $(+40 \mathrm{mV})$ responses recorded from GluA1-GFP- or GluA1ct-GFP-expressing and neighboring nonexpressing (Ctrl) neurons from Fmr1 knockout mice cultured in medium containing $75 \mu \mathrm{M}$ histamine (HA) and additional $10 \mu$ M SKF81297. (Bottom) Amplitudes (ctrl: $-30.3 \pm 2.4$ pA; exp: $-31.4 \pm 2.6$ pA; $n=31$; $P=0.46$ ) and rectifications (ctrl: $1.59 \pm 0.11$; exp: $1.81 \pm 0.09 ; n=31 ; P<0.05$ ) of synaptic AMPA responses in GluA1-GFP-expressing neurons or amplitudes of synaptic AMPA (ctrl: $-22.7 \pm 1.7 \mathrm{pA}$; exp: $-19.1 \pm 2.0 \mathrm{pA}$; $n=24 ; P<0.05$ ) and NMDA (ctrl: $48.0 \pm 4.1$ pA; exp: $44.1 \pm 4.6 \mathrm{pA} ; n=24 ; P=0.27)$ responses in GluA1-GFP-expressing neurons are plotted against those obtained from nonexpressing neurons. $(B$, top $)$ Evoked AMPAR-mediated $(-60 \mathrm{mV})$ responses recorded from GluAl-GFP-expressing and neighboring nonexpressing (Ctrl) neurons from Fmr1 knockout mice cultured in medium containing $75 \mu \mathrm{M}$ histamine (HA) and additional $10 \mu \mathrm{M}$ Quin or $10 \mu \mathrm{M}$ SKF81297 and $10 \mu \mathrm{M}$ Quin. (Bottom) Amplitudes (ctrl: $-31.4 \pm 2.3 \mathrm{pA}$; exp: $-29.0 \pm 2.4 \mathrm{pA}_{;} n=30 ; P=0.35$ for Quin; ctrl: $-42.8 \pm 3.7 \mathrm{pA}$; exp: $-39.9 \pm 3.7 \mathrm{pA} ; n=21 ; P=0.77$ for SKF and Quin) and rectifications (ctrl: $1.93 \pm 0.15$; exp: $1.96 \pm 0.08 ; n=30 ; P=0.41$ for Quin; ctrl: $1.66 \pm 0.10$; exp: $1.73 \pm 0.11 ; n=21 ; P=0.59$ for SKF and Quin) of synaptic AMPA responses in GluA1-GFP-expressing neurons are plotted against those obtained from nonexpressing neurons. The red dots indicate the averages, and scale bars apply to all recording traces. Statistical significances were determined with Wilcoxon tests. 
nonexpressing neurons, which could be fitted by a sigmoid function with the half-maximal effective concentration of $\sim 100$ nM (Supplemental Fig. S3; Supplemental Table S1). Similarly, we cultured GluA1-GFP-expressing Fmr1 knockout neurons in media with varied concentrations of SKF81297 and subsequently measured its effects on synaptic GluA1 delivery. Increasing the concentration of SKF81297 from $50 \mathrm{nM}$ to $50 \mu \mathrm{M}$ increased the relative rectification of AMPA responses in GluA1-GFP-expressing neurons compared with nonexpressing neurons, which could be fitted by a sigmoid function with the halfmaximal effective concentration of $\sim 2 \mu \mathrm{M}$ (Supplemental Fig. S3; Supplemental Table S2). Because the maximal rectification enhancement of AMPA responses in GluA1GFP-expressing neurons and maximal amplitude reduction of AMPA responses in GluAlct-GFP-expressing neurons of wild-type mice can reach $\sim 30 \%-40 \%$ (Hu et al. 2008; Myers et al. 2012), the rectification and amplitude changes in AMPA responses $(\sim 15 \%-20 \%)$ in 5HT- or DA-stimulated GluA1-GFP- and GluAlct-GFP-expressing neurons of Fmr1 knockout mice indicates a partial $(\sim 50 \%)$ rescue of synaptic GluA1 delivery.

We hypothesized that combinations of $5 \mathrm{HT}$ and DA modulators may fully restore the normal synaptic GluA1 delivery in Fmr1 knockout mice. Surprisingly, in the presence of $1 \mu \mathrm{M}$ BW723C86 and $10 \mu \mathrm{M}$ SKF81297 along with histamine, GluA1-GFP-expressing neurons of Fmr1 knockout mice had no significant enhancement in the rectification of AMPA responses compared with nearby nonexpressing neurons (Fig. 3A), suggesting little synaptic delivery of GluA1. Clinical data have documented that low doses of the drugs often work better in improving cognitive performance in fragile $\mathrm{X}$ patients, as high-dose $5 \mathrm{HT}$ and DA signaling-enhancing stimulants frequently induce the unwanted side effects related to anxiety (Hagerman et al. 2009). Therefore, we cultured CA1 neurons of Fmr1 knockout mice in medium containing histamine with lower concentrations of $5 \mathrm{HT}_{2 \mathrm{~B}}-\mathrm{R}$ and $\mathrm{D}_{1}$-R agonists. GluA1-GFP-expressing neurons of Fmr1 knockout mice cultured in medium containing the immediate concentrations of BW723C86 (100 nM) and SKF81297 $(1 \mu \mathrm{M})$ but not the very low concentrations of BW723C86 (10 nM) and SKF81297 (100 nM) had significantly enhanced rectification (by $\sim 30 \%$ ) of AMPA responses (Fig. 3A). Moreover, GluAlct-GFP-expressing neurons of Fmr1 knockout mice cultured in medium containing $100 \mathrm{nM}$ BW723C86 and $1 \mu \mathrm{M}$ SKF81297 showed $\sim 30 \%$ reduction in AMPA responses but unaltered NMDA responses (Fig. 3B). To determine the agonist dose response curves for coapplied $5 \mathrm{HT}$ and DA compounds, we cultured GluA1-GFP-expressing neurons in media with varied concentrations of BW723C86 and SKF81297 and subsequently measured their effects on synaptic GluA1 delivery. Increasing the concentrations of coapplied BW723C86 and SKF81297 dynamically altered the relative rectification of AMPA responses in GluA1-GFP-expressing neurons, which could be fitted by a Gaussian function with the maximal effective concentrations of $123 \mathrm{nM}$ and $1.23 \mu M$ for BW723C86 and SKF81297, respectively (Supplemental Fig. 3S; Supplemental Table S3). Collectively,
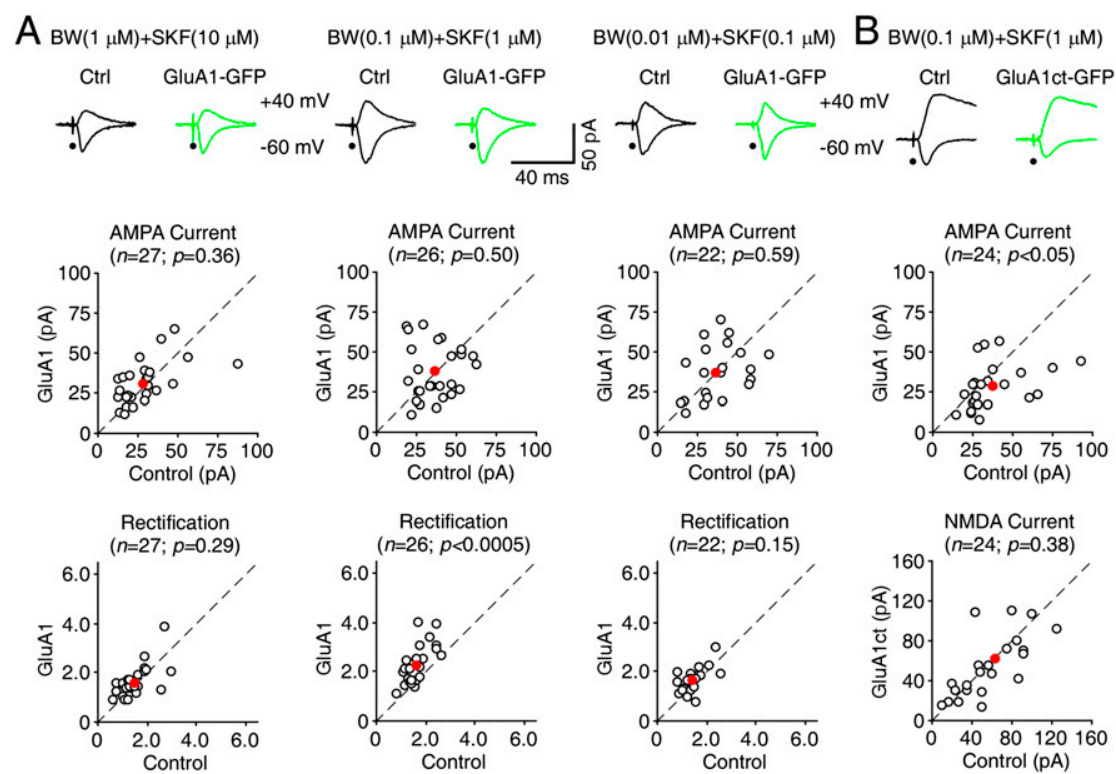

Figure 3. Coactivation of $5 \mathrm{HT}_{2 \mathrm{~B}}-\mathrm{Rs}$ and $\mathrm{D}_{1}$-Rs maximizes synaptic GluAl trafficking in Fmr1 knockout (KO) mice. $(A$, top) Evoked AMPA-R-mediated $(-60 \mathrm{mV})$ responses recorded from GluA1-GFP-expressing and neighboring nonexpressing (Ctrl) neurons from Fmr1 knockout mice cultured in medium containing $75 \mu \mathrm{M}$ histamine $(\mathrm{HA})$ and different concentrations of BW723C86 and SKF81297. (Bottom) Amplitudes and rectifications of synaptic AMPA responses in GluA1-GFP-expressing neurons cultured with $1 \mu \mathrm{M}$ BW723C86 and $10 \mu \mathrm{M}$ SKF81297 (ctrl: $-30.5 \pm 3.2 \mathrm{pA}$; exp: $-31.7 \pm 2.5$ pA; $n=27 ; P=0.36$ for amplitude; ctrl: $1.59 \pm$ 0.11 ; exp: $1.64 \pm 0.12 ; n=27 ; P=0.29$ for rectification), $0.1 \mu \mathrm{M}$ BW723C 86 and $1 \mu \mathrm{M}$ SKF81297 (ctrl: $-38.5 \pm 2.6 \mathrm{pA}$; exp: $-38.1 \pm$ $3.2 \mathrm{pA} ; n=26 ; P=0.50$ for amplitude; ctrl: $1.76 \pm 0.09$; exp: $2.29 \pm 0.15 ; n=26 ; P<$ 0.0005 for rectification), or $0.01 \mu \mathrm{M}$ BW723C86 and $0.1 \mu \mathrm{M}$ SKF81297 (ctrl: $-38.8 \pm 3.3 \mathrm{pA} ;$ exp: $-37.4 \pm 3.6 \mathrm{pA} ; n=$ 22; $P=0.59$ for amplitude; ctrl: $1.57 \pm 0.10$; exp: $1.68 \pm 0.11 ; n=22 ; P=0.15$ for rectification) are plotted against those obtained from nonexpressing neurons. $(B$, top $)$ Evoked AMPA-R-mediated $(-60 \mathrm{mV})$ and NMDA-R-mediated $(+40 \mathrm{mV})$ responses recorded from GluA1ct-GFP-expressing and neighboring nonexpressing (Ctrl) neurons from Fmr1 knockout mice cultured in medium containing 75 $\mu \mathrm{M}$ histamine (HA) and additional $0.1 \mu \mathrm{M}$ BW723C86 and $1 \mu \mathrm{M}$ SKF81297. (Bottom) Amplitudes of synaptic AMPA (ctrl: -39.7 \pm 3.9 pA; exp: $-29.0 \pm 2.9$ pA; $n=24 ; P<0.05$ ) and NMDA (ctrl: $66.5 \pm 8.1$ pA; exp: $63.5 \pm 8.5$ pA; $n=24 ; P=0.38$ ) responses in GluA1GFP-expressing neurons are plotted against those obtained from nonexpressing neurons. The red dots indicate the averages, and scale bars apply to all recording traces. Statistical significances were determined with Wilcoxon tests. 
these results suggest that partial activation of both $5 \mathrm{HT}_{2 \mathrm{~B}}$-Rs and $\mathrm{D}_{1}$-Rs synergistically drives more synaptic delivery of GluA1.

To determine whether activation of $5 \mathrm{HT}_{2 \mathrm{~B}}$-Rs and/or $\mathrm{D}_{1}$-Rs may also stimulate synaptic delivery of GluAl in wild-type mice, we cultured GluA1-GFP-expressing wildtype neurons in medium containing $5 \mathrm{HT}$ and/or DA modulators. In the presence of $1 \mu \mathrm{M}$ BW723C86, $10 \mu \mathrm{M}$ SKF81297, or $100 \mathrm{nM} \mathrm{BW723C86}$ and $1 \mu \mathrm{M}$ SKF81297, GluA1-GFP-expressing wild-type neurons had enhanced rectification (by $\sim 30 \%$ ) of AMPA responses compared with nearby control nonexpressing neurons, and GluAlctGFP-expressing wild-type neurons had depressed ( 30\%) AMPA responses (Supplemental Fig. S4). The increase in rectification and decrease in amplitude of AMPA responses are comparable with wild-type neurons cultured in normal medium, suggesting no additional effects of $5 \mathrm{HT}$ and/or DA modulators on synaptic delivery of GluA1 in wild-type mice, which is already maximal in wild-type animals ( $\mathrm{Hu}$ et al. 2008; Myers et al. 2012).

\section{HT and DA drug cocktail restores normal synaptic plasticity in Fmrl knockout mice}

To determine whether 5HT- and DA-stimulated synaptic GluA1 delivery may rescue the impaired LTP in Fmr1 knockout mice, we measured LTP in CA1 neurons in cultured slices prepared from wild-type and Fmr1 knockout mice. Fmr1 knockout neurons had reduced LTP (by $\sim 50 \%$ ) compared with wild-type neurons (Fig. 4), consistent with the previous finding that GluA1-dependent, but not GluA2L-dependent, LTP was selectively impaired in
Fmr1 knockout mice (Qin et al. 2005; Hu et al. 2008). In the presence of $1 \mu \mathrm{M}$ BW723C86 or $10 \mu \mathrm{M}$ SKF81297, LTP in Fmr1 knockout neurons slightly increased, reaching close to $\sim 70 \%$ of that in wild-type neurons (Fig. 4), suggesting a partial rescue. In the presence of $100 \mathrm{nM}$ BW723C86 and $1 \mu$ M SKF81297, LTP in Fmr1 knockout neurons further increased to a level comparable with that in wild-type neurons (Fig. 4). In the same experiments, we also measured LTP in GluAlct-GFP-expressing neurons. In the presence of $100 \mathrm{nM} \mathrm{BW723C86}$ and $1 \mu \mathrm{M}$ SKF81297, GluA1ct-GFP-expressing Fmr1 knockout neurons had reduced LTP (by $\sim 50 \%$ ) compared with nearby nonexpressing neurons (Fig. 4), suggesting a blockade of 5HT and DA modulator cocktail-enhanced LTP. Together, these results suggest that the low dose of 5HT and DA modulator cocktail restores the normal GluA1-dependent LTP in Fmr1 knockout mice.

\section{HT and DA drug cocktail restores normal synaptic GluA1 delivery Fmr1 knockout mice in vivo}

We next examined whether 5HT or DA modulators stimulate synaptic delivery of GluA1 Fmr1 knockout mice in intact brains. Combining an in vivo viral delivery technique and an acute slice preparation (McCormack et al. 2006; Zhu 2009), we virally expressed GluAl-GFP in CA1 pyramidal neurons in Fmr1 knockout mice in vivo, administered 5HT or DA modulators through intraperitoneal (i.p.) injection, and subsequently measured AMPA responses in these neurons in acutely prepared slices (Fig. 5A). With the i.p. coadministration of $5 \mathrm{mg} / \mathrm{kg}$ BW723C86 and $1 \mathrm{mg} / \mathrm{kg}$ MDL11939, GluA1-GFP-expressing
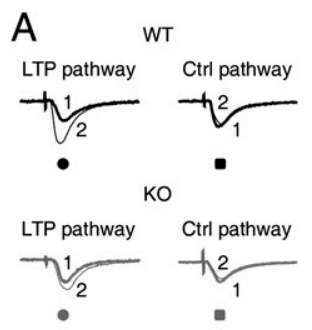

B

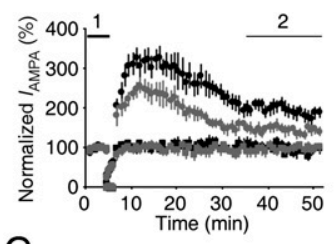

C

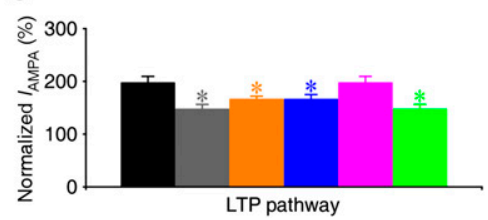

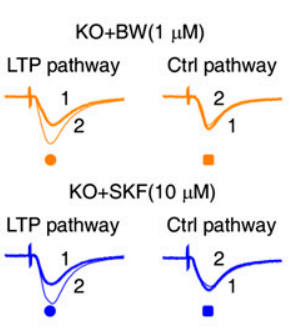
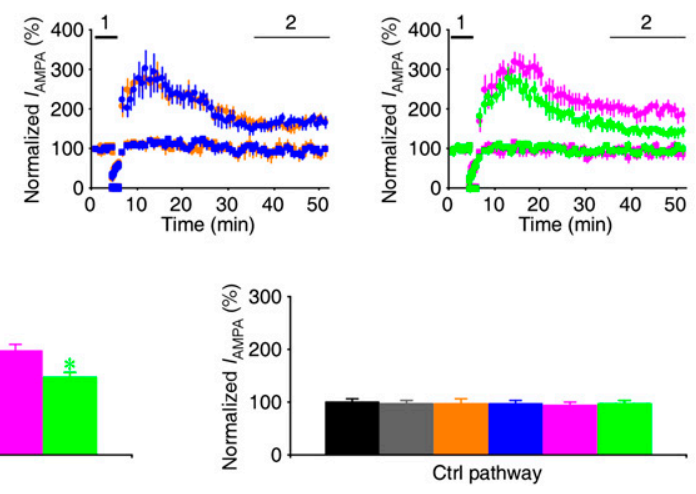

Figure 4. Coactivation of $5 \mathrm{HT}_{2 \mathrm{~B}}$-Rs and $\mathrm{D}_{1}$-Rs restores normal LTP in Fmr1 knockout (KO) mice. (A) Average AMPA-R-mediated synaptic responses obtained before $(-60 \mathrm{mV}$; thick trace $)$ and after $(-60 \mathrm{mV}$; thin trace) LTP-inducing pairing in paired (left) and control (right) pathway in wild-type (WT) and Fmr1 knockout CA1 neurons in normal bath solution or bath solution containing additional $1 \mu \mathrm{M}$ BW723C86, $10 \mu \mathrm{M}$ SKF81297, $0.1 \mu \mathrm{M}$ BW723C86, and $1 \mu \mathrm{M}$ SKF81297 or in GluAlct-GFP-expressing Fmr1 knockout CA1 neurons in bath solution containing $0.1 \mu \mathrm{M}$ BW723C86 and $1 \mu \mathrm{M}$ SKF81297. (B) Normalized evoked responses recorded from all CA1 neurons against time. $(C)$ Relatively steadystate AMPA response amplitudes in paired (WT: $197.6 \pm 11.7 \%, n=14$; KO: $147.2 \pm 9.5 \%, n=15$; $P<0.005 ; \mathrm{KO}+1 \mu \mathrm{M}$ BW: $164.7 \pm 8.7 \%, n=16$; $P<0.05 ;$ KO $+10 \mu$ M SKF: $166.0 \pm 9.6 \%, n=16 ; P<$ 0.05 ; KO+0.1 $\mu \mathrm{M}$ BW+1 $\mu \mathrm{M}$ SKF: $198.2 \pm 11.5 \%$, $n=14 ; P=0.98 ;$ KO-GluAlct $+0.1 \mu \mathrm{M} \mathrm{BW}+1 \mu \mathrm{M}$ SKF: $148.0 \pm 8.2 \%, n=14 ; P<0.01$ ) and control (WT: $99.6 \pm 7.4 \%, n=14$; KO: $98.3 \pm 6.2 \%, n=$ $15 ; P=0.88$; KO+1 $\mu \mathrm{M}$ BW: $96.1 \pm 10.9 \%, n=16$; $P=0.82$; KO+10 $\mu$ M SKF: $96.2 \pm 5.5 \%, n=16$; $P=0.76 ; \mathrm{KO}+0.1 \mu \mathrm{M}$ BW+1 $\mu \mathrm{M}$ SKF: $92.9 \pm 7.2 \%$, $n=14 ; P=0.77$; KO-GluAlct $+0.1 \mu \mathrm{M}$ BW+1 $\mu \mathrm{M}$ SKF: $96.0 \pm 6.8 \%, n=14 ; P=0.84$ ) pathways in wild-type or Fmr1 knockout CA1 neurons in normal bath solution or bath solution containing $1 \mu \mathrm{M}$ BW723C86, $0.1 \mu \mathrm{M}$ BW723C86, and $1 \mu \mathrm{M}$ SKF81297 or in GluA1ct-GFPexpressing Fmr1 knockout CA1 neurons in bath solution containing $0.1 \mu$ M BW723C86 and $1 \mu$ M SKF81297. Asterisks indicate $P<0.05$ (Mann-Whitney Rank Sum tests). 
neurons had the same amplitude but enhanced rectification (by $\sim 15 \%$ ) of AMPA responses compared with nearby nonexpressing neurons (Fig. 5B), suggesting that activating $5 \mathrm{HT}_{2 \mathrm{~B}}$-Rs and inhibiting $5 \mathrm{HT}_{2 \mathrm{~A}}$-Rs partially stimulated synaptic GluA1 delivery in Fmr1 knockout mice in vivo. Similarly, with the i.p. coadministration of $5 \mathrm{mg} / \mathrm{kg}$ SKF81297 and $25 \mathrm{mg} / \mathrm{kg}$ sulpiride (SUL), a $\mathrm{D}_{2}$ antagonist, GluA1-GFP-expressing neurons had the same amplitude but enhanced rectification (by $\sim 15 \%$ ) of AMPA responses (Fig. $5 \mathrm{~B}$ ), suggesting that activating $\mathrm{D}_{1}$-Rs and inhibiting $\mathrm{D}_{2}$-Rs partially stimulated synaptic GluA1 delivery in Fmr1 knockout mice in vivo.

To test whether a cocktail of $5 \mathrm{HT}$ and DA compounds at low doses may stimulate more synaptic GluA1 delivery in vivo, we coadministered $0.05 \mathrm{mg} / \mathrm{kg}$ BW723C86, 0.01 $\mathrm{mg} / \mathrm{kg}$ MDL11939, $0.05 \mathrm{mg} / \mathrm{kg}$ SKF81297, and $0.25 \mathrm{mg} / \mathrm{kg}$ SUL in Fmr1 knockout mice during in vivo expression of GluA1-GFP in CA1 neurons. GluA1-GFP-expressing neurons of Fmr1 knockout mice administered with this drug cocktail had the same amplitude but enhanced rectification (by $\sim 40 \%$ ) of AMPA responses (Fig. 5C). Moreover, GluA1ct-GFP-expressing neurons of Fmr1 knockout mice administered with the drug cocktail had reduced AMPA (by $\sim 30 \%$ ) but unaltered NMDA responses (Fig. $5 \mathrm{C}$ ). The amount of increase in rectification of AMPA responses in GluA1-GFP-expressing Fmr1 knockout neurons and the amount of decrease in amplitude of AMPA responses in GluA1ct-GFP-expressing Fmr1 knockout neurons are comparable with those observed in wild-type neurons (cf. Hu et al. 2008; Myers et al. 2012), suggesting that partially activating both $5 \mathrm{HT}_{2 \mathrm{~B}}-\mathrm{Rs}$ and $\mathrm{D}_{1}$-Rs and inhibiting both $5 \mathrm{HT}_{2 \mathrm{~A}}$-Rs and $\mathrm{D}_{2}$-Rs restores the normal synaptic GluA1 trafficking in Fmr1 knockout mice in vivo.

To determine whether 5HT or DA modulators stimulate synaptic delivery of GluA1 in Fmr1 knockout mice in vivo in general, we examined synaptic delivery of GluA1 in another type of neuron, L2/3 cortical pyramidal neurons of Fmr1 knockout mice (Supplemental Fig. S5A), which also display impaired synaptic GluA1 delivery in Fmr1 knockout mice (Hu et al. 2008). With the i.p. coadministration of $5 \mathrm{mg} / \mathrm{kg} \mathrm{BW723C86}$ and $1 \mathrm{mg} / \mathrm{kg}$ MDL11939 or $5 \mathrm{mg} / \mathrm{kg}$ SKF81297 and $25 \mathrm{mg} / \mathrm{kg}$ SUL, GluA1-GFPexpressing L2/3 pyramidal neurons of Fmr1 knockout mice had the same amplitude but enhanced rectification (by $\sim 15 \%$ ) of AMPA responses compared with nearby nonexpressing neurons (Supplemental Fig. S5B), suggesting a partial rescue of synaptic GluAl delivery. With the i.p. coadministration of $0.05 \mathrm{mg} / \mathrm{kg}$ BW723C $86,0.01 \mathrm{mg} / \mathrm{kg}$ MDL11939, $0.05 \mathrm{mg} / \mathrm{kg}$ SKF81297, and $0.25 \mathrm{mg} / \mathrm{kg}$ SUL, GluA1-GFP-expressing L2/3 pyramidal neurons of Fmr1 knockout mice had the same amplitude but enhanced rectification (by $\sim 35 \%$ ) of AMPA responses, and GluAlct-GFP-expressing neurons of Fmr1 knockout mice had reduced AMPA (by $\sim 30 \%$ ) but unaltered NMDA responses (Supplemental Fig. S5C), suggesting a restoration of the normal synaptic GluA1 delivery. Collectively, these
A GluA1- or GluA1ct-GFP

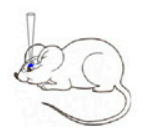

B BW $(5 \mathrm{mg} / \mathrm{kg})+$ MDL (1 mg/kg)

Ctrl GluA1-GFP

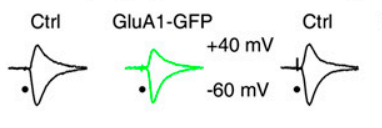

SKF $(5 \mathrm{mg} / \mathrm{kg})+$ SUL $(25 \mathrm{mg} / \mathrm{kg})$

Ctrl GluA1-GFP
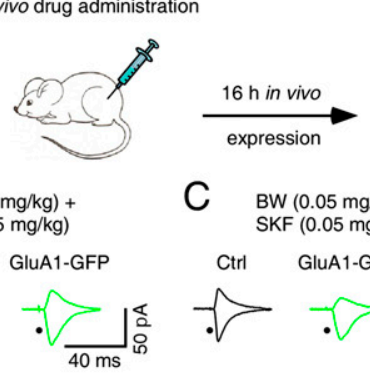

Electrophysiology (evoked EPSCs)

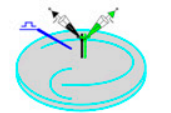
SKF $(0.05 \mathrm{mg} / \mathrm{kg})+\mathrm{SUL}(0.25 \mathrm{mg} / \mathrm{kg})$
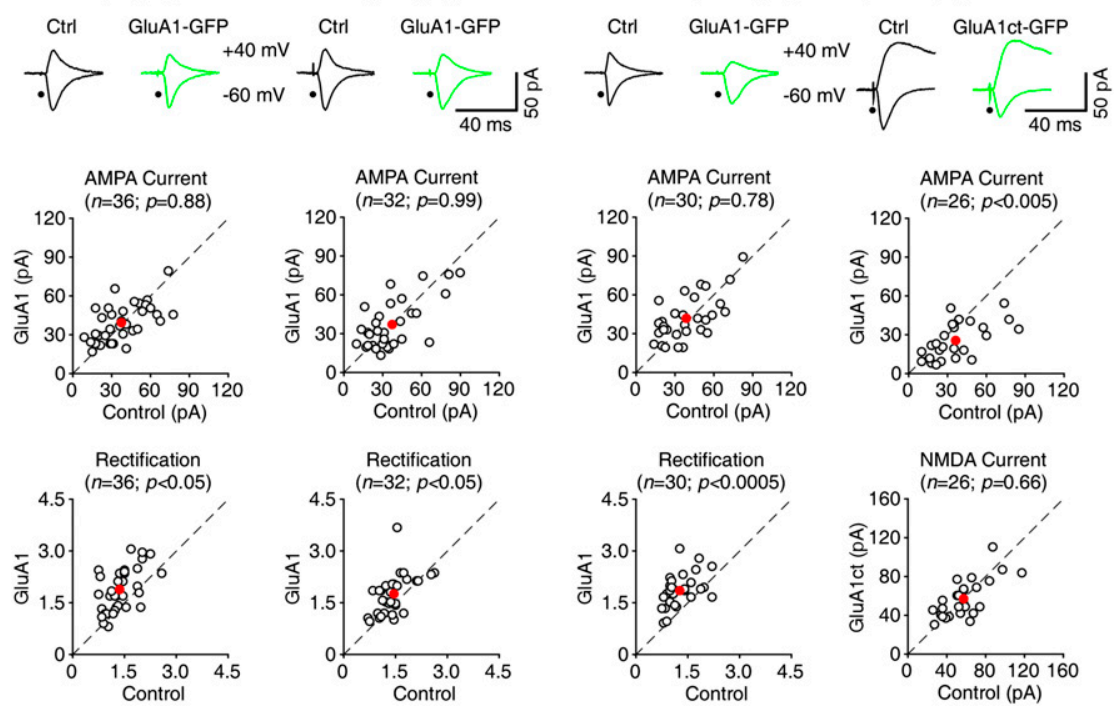

C $\quad B W(0.05 \mathrm{mg} / \mathrm{kg})+\mathrm{MDL}(0.01 \mathrm{mg} / \mathrm{kg})+$

Figure 5. $5 \mathrm{HT}_{2 \mathrm{~B}}$-Rs and/or $\mathrm{D}_{1}$-Rs stimulate synaptic GluA1 trafficking in Fmr1 knockout (KO) mice in vivo. (A) Schematic drawing outlines the in vivo experimental design. $(B$, top) Evoked AMPA-R-mediated $(-60 \mathrm{mV})$ responses recorded from GluA1-GFP-expressing and neighboring nonexpressing (Ctrl) neurons from Fmr1 knockout mice administered i.p. with $5 \mathrm{mg} / \mathrm{kg} \mathrm{BW723C86}$ and $1 \mathrm{mg} / \mathrm{kg}$ MDL11939 or $5 \mathrm{mg} / \mathrm{kg}$ SKF81297 and 25 $\mathrm{mg} / \mathrm{kg}$ SUL. (Bottom) Amplitudes (ctrl: $-39.9 \pm$ 3.0 pA; exp: $-39.5 \pm 2.4$ pA; $n=36 ; P=$ 0.88 for BW and MDL; ctrl: $-38.6 \pm 3.6 \mathrm{pA}$; exp: $-38.7 \pm 3.7 \mathrm{pA} ; n=32 ; P=0.99$ for $\mathrm{SKF}$ and SUL) and rectifications (ctrl: $1.47 \pm 0.08$; exp: $1.71 \pm 0.10 ; n=36 ; P<0.05$ for BW and MDL; ctrl: $1.53 \pm 0.08$; exp: $1.76 \pm 0.10 ; n=$ 32; $P<0.05$ for SKF and SUL) of synaptic AMPA responses in GluA1-GFP-expressing neurons are plotted against those obtained from nonexpressing neurons. $(C$, top $)$ Evoked AMPA-R-mediated $(-60 \mathrm{mV})$ or AMPA-Rmediated $(-60 \mathrm{mV})$ and NMDA-R-mediated $(-60 \mathrm{mV})$ responses recorded from GluA1GFP- or GluAlct-GFP-expressing and neighboring nonexpressing (Ctrl) neurons from Fmr1 knockout mice administered i.p.

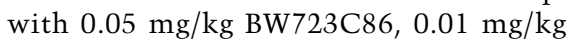
MDL11939, $0.05 \mathrm{mg} / \mathrm{kg}$ SKF81297, and $0.25 \mathrm{mg} / \mathrm{kg}$ SUL. (Bottom) Amplitudes (ctrl: $-41.7 \pm 3.4 \mathrm{pA}$; exp: $-42.8 \pm 3.2 \mathrm{pA} ; n=30 ; P=0.78$ ) and rectifications (ctrl: $1.35 \pm$ 0.08; exp: $1.88 \pm 0.09 ; n=30 ; P<0.0005)$ of synaptic AMPA responses in GluA1-GFP-expressing neurons and amplitudes of synaptic AMPA (ctrl: $-39.2 \pm 4.0$ pA; exp: $-26.7 \pm 2.4$ pA; $n=26 ; P<0.005$ ) and NMDA (ctrl: $61.1 \pm 4.3$ pA; exp: $58.2 \pm 3.8$ pA; $n=26 ; P=$ $0.66)$ responses in GluAlct-GFP-expressing neurons are plotted against those obtained from nonexpressing neurons. The red dots indicate the averages, and scale bars apply to all recording traces. Statistical significances were determined with Wilcoxon tests. 
results suggest that the low-dose $5 \mathrm{HT}$ and DA drug cocktail restores the normal synaptic GluA1 trafficking in Fmr1 knockout mice in vivo.

\section{HT and DA drug cocktail stimulates Ras-PI3K/PKB signal transduction in Fmrl knockout mice}

To understand how 5HT and DA modulators, particularly the low-dose 5HT and DA drug cocktail, may stimulate synaptic GluA1 trafficking in Fmr1 knockout mice, we examined the effects of those modulators on Ras-PI3K/ $\mathrm{PKB}$ signal transduction, which is essential for synaptic GluA1 trafficking (Qin et al. 2005; Hu et al. 2008; Kielland et al. 2009). We first measured the levels of the active form of Ras (GTP-bound Ras) in CA1 cells prepared from both sleeping and awake wild-type and Fmr1 knockout mice, since the dynamic Ras activity depends on the behavioral state of animals (Qin et al. 2005; Hu et al. 2008). In both wild-type and Fmr1 knockout mice, the levels of the active form of Ras (GTP-bound Ras) in CA1 cells of awake animals were significantly higher than those in sleeping animals (Fig. 6A). However, Fmr1 knockout mice had elevated basal levels of Ras-GTP during sleeping and reduced ranges of Ras activation between sleeping and awake states compared with wild-type mice, suggesting reduced Ras signaling dynamics in knockout mice. Further analysis revealed that in wild-type mice, but not Fmr1 knockout mice, the levels of phosphorylated PKB in CA1 cells of awake animals were significantly higher than those in sleeping animals (Fig. 6B), suggesting diminished PKB signaling dynamics in knockout mice. These results suggest that signal transduction from Ras to PI3K/PKB is compromised in Fmr1 knockout mice.

We then analyzed the effects of 5HT and DA modulators on Ras-PI3K/PKB signaling in Fmr1 knockout mice in the awake state, during which GluA1 is delivered to synapses (Qin et al. 2005; Hu et al. 2008). Administration i.p. of $5 \mathrm{mg} / \mathrm{kg}$ BW723C86 and $1 \mathrm{mg} / \mathrm{kg}$ MDL11939 or $5 \mathrm{mg} / \mathrm{kg}$ SKF81297 and $25 \mathrm{mg} / \mathrm{kg}$ SUL significantly increased the levels of Ras-GTP (by $\sim 30 \%$ ) and phosphorylated PKB (by $\sim 30 \%$ ) in CA1 cells of Fmr1 knockout mice (Fig. 6C,D), suggesting increases in signaling inputs to the Ras-PI3K/PKB signaling pathway. In contrast, coadministration of the low-dose $5 \mathrm{HT}$ and DA compounds, including $0.05 \mathrm{mg} / \mathrm{kg}$ BW723C86, $0.01 \mathrm{mg} / \mathrm{kg}$ MDL11939, $0.05 \mathrm{mg} / \mathrm{kg}$ SKF81297, and $0.25 \mathrm{mg} / \mathrm{kg}$ SUL, had only a limited effect on the levels of Ras-GTP but induced larger enhancements of levels of phosphorylated PKB in CA1 cells of Fmr1 knockout mice (Fig. 6C,D), suggesting a major effect on PI3K/PKB activity. These results suggest that the low-dose $5 \mathrm{HT}$ and DA drug cocktail can restore normal PKB signaling by primarily enhancing signal transduction between Ras and PI3K/PKB in Fmr1 knockout mice.

\section{HT and DA drug cocktail rescues learning deficits in Fmr1 knockout mice}

To determine whether administration of $5 \mathrm{HT}$ and/or DA compounds may improve cognitive performance of Fmr1 knockout mice, we first analyzed the learning behavior of wild-type and Fmr1 knockout mice using standard fear conditioning (Supplemental Fig. S6A). During the fear conditioning training, Fmr1 knockout mice had the same responses to a tone presentation and electrical foot shock and exhibited the same amount of freezing compared with wild-type mice (Supplemental Fig. S6B). During the testing $24 \mathrm{~h}$ after fear conditioning, Fmr1 knockout mice displayed a small but insignificant reduction in the amount of freezing compared with wild-type mice (Supplemental Fig. S6B). These results are consistent with the previous reports that Fmr1 knockout mice exhibited modest impairments in this form of associative learning, with the differences in the amount of freezing between knockout and wild-type mice being either slightly above (Paradee et al. 1999; Van Dam et al. 2000) or below (Dobkin et al. 2000) the statistical significance.

To effectively test the cognitive effects of $5 \mathrm{HT}$ and DA modulators, we examined a more demanding associative learning (Fig. 7A), the trace fear conditioning paradigm, which is sensitive to attention-distracting stimuli (Han et al. 2003) and severely impaired in Fmr1 knockout mice (Zhao et al. 2005; Hayashi et al. 2007; Guo et al. 2011). During trace fear conditioning, Fmr1 knockout and wildtype mice displayed the same amounts of freezing (Fig. 7B). When tested $24 \mathrm{~h}$ after the trace fear conditioning, Fmr1 knockout mice exhibited significantly reduced freezing compared with wild-type mice (Fig. 7C; Supplemental Movies S1, S2). Administration of $5 \mathrm{mg} / \mathrm{kg}$ BW723C86 and $1 \mathrm{mg} / \mathrm{kg}$ MDL11939 or $5 \mathrm{mg} / \mathrm{kg}$ SKF81297 and $25 \mathrm{mg} / \mathrm{kg}$ SUL induced anxiety-related behavior changes in many Fmr1 knockout mice; some drug-treated Fmr1 knockout mice traveled a significantly longer distance and made significantly more crossings of the center field in the training and testing chambers compared with control wild-type mice (Supplemental Fig. S7; Supplemental Table S4; cf. Hayashi et al. 2007). Because hyperactivity (i.e., increased locomotion and center crossing) may impair learning and prevent an accurate measurement of the amounts of learning-induced change in freezing, we excluded the Fmr1 knockout mice that displayed two or more standard deviation increases in these measurements from the analysis (Supplemental Table S4). Analysis of learning behavior of the remaining Fmr1 knockout mice showed that 5 HT or DA compound administration did not change the amount of freezing during the training but slightly increased freezing during the tone test compared with control Fmr1 knockout mice (Fig. 7B,C). These results suggest a modest improvement in the associative learning in the drug-treated Fmr1 knockout mice. Interestingly, coadministration of the low-dose 5HT and DA

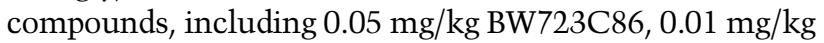
MDL11939, $0.05 \mathrm{mg} / \mathrm{kg} \mathrm{SKF81297,} \mathrm{and} 0.25 \mathrm{mg} / \mathrm{kg} \mathrm{SUL}$, induced no significant change in locomotion and center crossing (Supplemental Fig. S7; Supplemental Table S4). In addition, administering the drug cocktail had no effect on the amount of freezing during the training in Fmr1 knockout mice (Fig. 7B). Notably, during the tone test, Fmr1 knockout mice that received the drug cocktail exhibited the same amount of freezing as wild-type mice, enhanced compared with control Fmr1 knockout mice (Fig. 7C; Supplemental Movie S3). These results suggest 
A
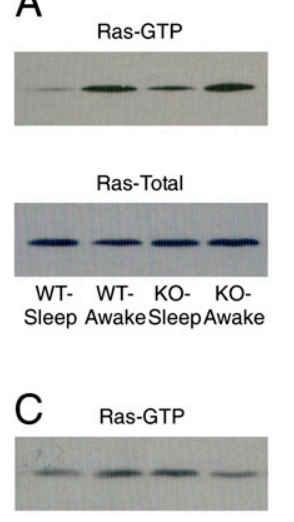

Ras-Total

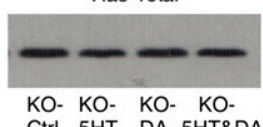

WT-Sleep WT-Awake
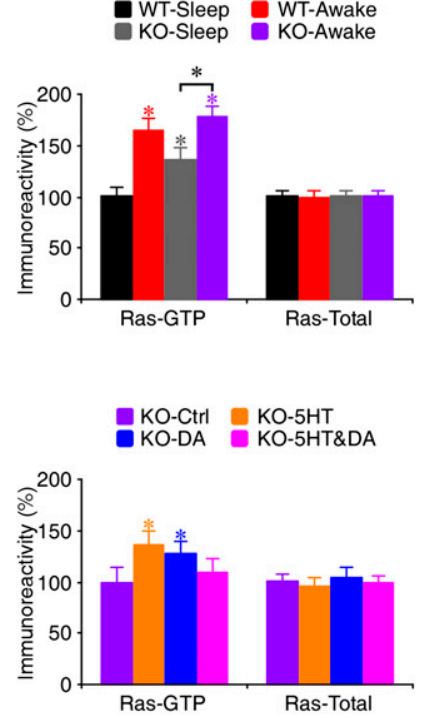

B
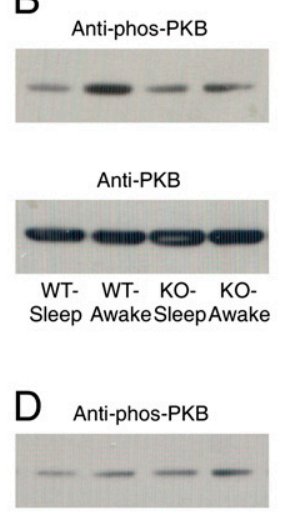

Anti-PKB

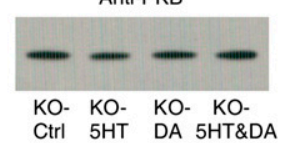

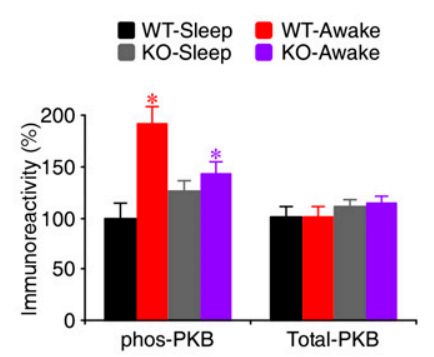

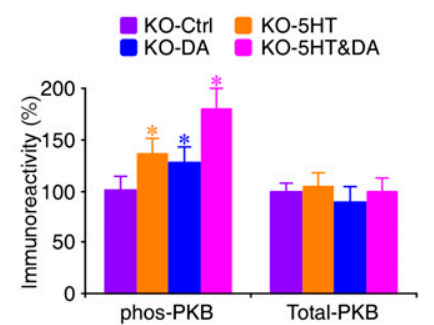

Figure 6. $5 \mathrm{HT}_{2 \mathrm{~B}}$-Rs and/or $\mathrm{D}_{1}$-Rs stimulate Ras-PI3K/PKB signaling in Fmr1 knockout (KO) mice in vivo. (A, left) Blots of GTP-bound Ras and total Ras in CA1 tissues of sleeping and awake Fmr1 knockout and wild-type (WT) mice. (Right) Relative amounts of Ras-GTP in CA1 tissues prepared from awake wild-type mice (WT-Awake: $164.6 \pm 12.3 \% ; n=14 ; P<0.005$ ), sleeping knockout mice (KO-Sleep: $135.7 \pm 12.5 \% ; n=14 ; P<0.005)$, and awake knockout mice (KO-Awake: $178.2 \pm 10.8 \% ; n=14 ; P<0.005)$ compared with those prepared from sleeping wild-type mice (WT-Sleep: $100.0 \pm 10.0 \% ; n=14$ ) and relative amounts of total Ras in CA1 tissues prepared from awake wild-type mice (WT-Awake: $99.9 \pm 5.9 \% ; n=14 ; P=0.93)$, sleeping knockout mice (KO-Sleep: $100.9 \pm 5.3 \% ; n=14 ; P=$ 0.73), and awake knockout mice (KO-Awake: $101.2 \pm 4.6 \% ; n=14 ; P=0.95$ ) compared with those prepared from sleeping wild-type mice (WT-Sleep: $100.0 \pm 5.3 \% ; n=14)$. $(B$, left) Western blots of phos-PKB in hippocampal CA1 tissue prepared from sleeping and awake Fmr1 knockout and wild-type mice. (Right) Relative amounts of phos-PKB in CA1 tissues prepared from awake wild-type mice (WTAwake: $192.0 \pm 16.1 \% ; n=12 ; P<0.005$ ), sleeping knockout mice (KO-Sleep: $126.6 \pm 9.7 \% ; n=12 ; P=0.07$ ), and awake knockout mice (KO-Awake: $142.6 \pm 12.0 \% ; n=12 ; P<0.05$ ) compared with those prepared from sleeping wild-type mice (WT-Sleep: 100.0 $\pm 13.7 \%$; $n=12$ ) and relative amounts of total PKB in CA1 tissues prepared from awake wild-type mice (WT-Awake: $100.5 \pm 9.9 \% ; n=12 ; P=$ 0.88 ), sleeping knockout mice (KO-Sleep: $111.1 \pm 6.4 \% ; n=12 ; P=0.24)$, and awake knockout mice (KO-Awake: $115.0 \pm 6.5 \% ; n=12$; $P=0.18)$ compared with those prepared from sleeping wild-type mice (WT-Sleep: $100.0 \pm 11.2 \% ; n=12)$. (C, left) Blots of GTP-bound Ras and total Ras in CA1 tissues of awake control Fmr1 knockout mice and awake Fmr1 knockout mice with i.p. coadministration of 5HT compounds BW723C86 (5 mg/kg) and MDL1 1939 (1 mg/kg), DA compounds SKF81297 (5 mg/kg) and SUL (25 mg/kg), or 5HT and DA compounds BW723C86 (0.05 mg/kg), MDL11939 (0.01 mg/kg), SKF81297 (0.05 mg/kg), and SUL (0.25 mg/kg). (Right) Relative amounts of Ras-GTP in CA1 tissues prepared from 5HT compound-treated knockout mice (KO-5HT: $136.5 \pm 12.5 \% ; n=12 ; P<0.01$ ), DA compound-treated knockout mice (KO-DA: $128.5 \pm 10.7 \% ; n=12 ; P<0.05)$, and 5HT and DA compound-treated knockout mice (KO-5HT\&DA: $109.8 \pm 12.2 \% ; n=12 ; P=0.31$ ) compared with those prepared from control knockout mice (KO-Ctrl: $100.0 \pm 13.8 \%$; $n=12$ ) and relative amounts of total Ras in CA1 tissues prepared from $5 \mathrm{HT}$ compound-treated knockout mice (KO-5HT: $95.1 \pm 8.4 \%$; $n=12 ; P=0.39$ ), DA compound-treated knockout mice (KO-DA: $104.2 \pm 10.3 \% ; n=12 ; P=0.64$ ), and $5 \mathrm{HT}$ and DA compound-treated knockout mice (KO-5HT\&DA: $99.1 \pm 6.8 \% ; n=12 ; P=0.86)$ compared with those prepared from control knockout mice (KO-Ctrl: $100.0 \pm 8.0 \% ; n=12) .(D, 1$ eft $)$ Western blots of phos-PKB in hippocampal CA1 tissues of awake control Fmr1 knockout mice and awake Fmr1 knockout mice with i.p. coadministration of 5HT compounds BW723C86 (5 mg/kg) and MDL11939 (1 mg/kg), DA compounds SKF81297 (5 mg/kg) and SUL (25 mg/kg), or 5HT and DA compounds BW723C86 (0.05 mg/kg), MDL11939 (0.01 mg/kg), SKF81297 (0.05 $\mathrm{mg} / \mathrm{kg}$ ), and SUL $(0.25 \mathrm{mg} / \mathrm{kg})$. (Right) Relative amounts of phos-PKB in CAl tissues prepared from 5HT compound-treated knockout mice (KO-5HT: $136.6 \pm 14.5 \% ; n=12 ; P<0.05)$, DA compound-treated knockout mice (KO-DA: $127.0 \pm 15.8 \% ; n=12 ; P<0.05)$, and 5HT and DA compound-treated knockout mice (KO-5HT\&DA: $179.6 \pm 20.6 \% ; n=12 ; P<0.005)$ compared with those prepared from control knockout mice (KO-Ctrl: $100.0 \pm 15.1 \% ; n=12$ ) and relative amounts of total PKB in CA1 tissues prepared from 5HT compound-treated knockout mice (KO-5HT: $104.7 \pm 12.8 \% ; n=12 ; P=0.64$ ), DA compound-treated knockout mice (KO-DA: $89.3 \pm$ $14.7 \% ; n=12 ; P=0.10$ ), and 5HT and DA compound-treated knockout mice (KO-5HT\&DA: $98.9 \pm 14.3 \% ; n=12 ; P=0.82$ ) compared with those prepared from control knockout mice (KO-Ctrl: $100.0 \pm 7.4 \% ; n=12$ ). Note the significant difference in the levels of active Ras-GTP, but not phos-PKB, between sleeping and awake knockout mice. For each set of cell lysates, $35 \mu \mathrm{g}$ of protein was used to purify and blot GTP-bound Ras, $7.5 \mu \mathrm{g}$ of protein was used to directly blot total Ras, and $45 \mu \mathrm{g}$ of protein was used to blot phos-PKB and then reblot PKB after stripping. The relative values and standard errors were normalized to average amounts of Ras-GTP, phos-PKB, total Ras, or total PKB of CA1 tissues from sleeping wild-type mice or awake knockout mice. Asterisk indicates $P<0.05$ (Wilcoxon test).

that administration of a low-dose $5 \mathrm{HT}$ and DA drug cocktail restores normal associative learning in Fmr1 knockout mice without inducing anxiety-related side effects.

To confirm the low side effects associated with the low-dose 5HT and DA drug cocktail, we made additional measurements of anxiety-like behavior with an elevated plus maze apparatus and a light-dark two-chamber box. The elevated plus maze and light-dark exploration tests showed that Fmr1 knockout mice spent more time on the open arms of the elevated plus maze and in the light 
Lim et al.

\section{A Drug administration}
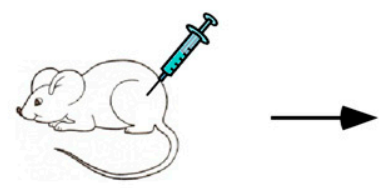

WT

$\mathrm{B}$

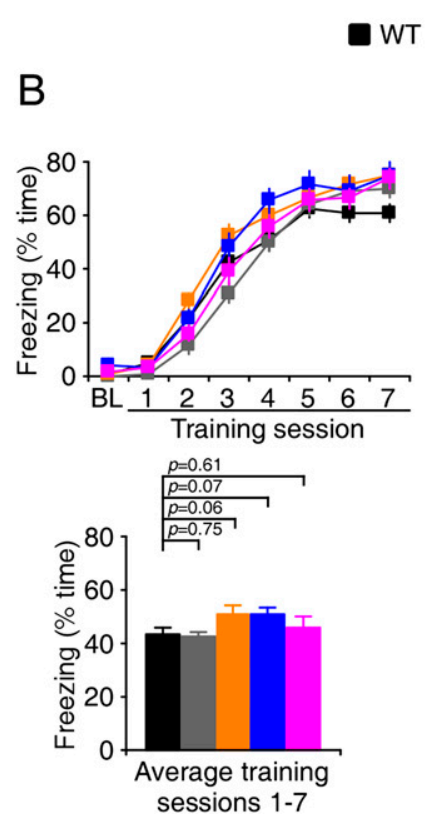

Trace conditioning \& tests

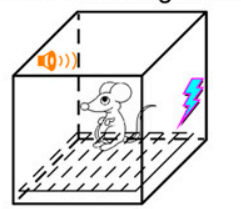

OR

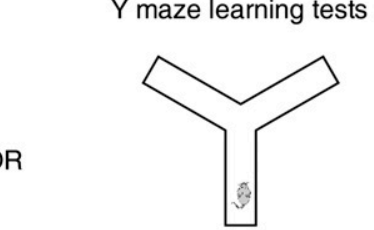

kO
C

KO-5HT\&DA
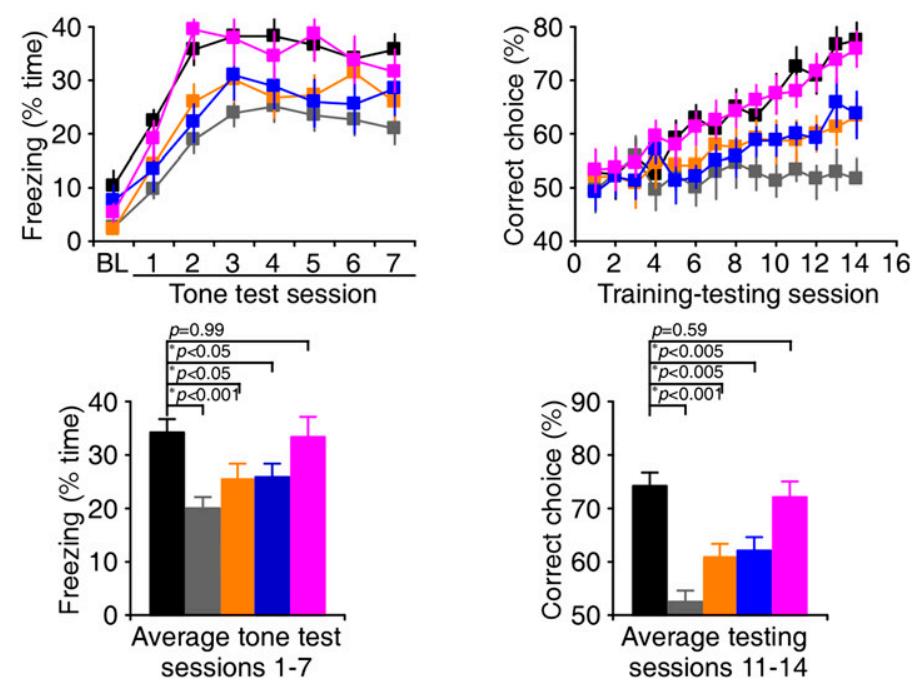

Figure 7. Cocktails of 5HT and DA compounds restore normal learning in Fmr1 knockout (KO) mice. (A) Schematic drawing outlines the behavioral testing design. $(B, t o p)$ During the trace fear conditioning, wild-type (WT) mice, knockout mice, and knockout mice administered i.p. with 5HT, DA, or 5HT and DA compounds exhibited comparable amounts of freezing. (Bottom) Histograms show that amounts of freezing during conditioning in wild-type mice $(43.4 \pm 2.5 \% ; n=24)$, knockout mice $(42.5 \pm 2.6 \% ; n=22)$, and knockout mice treated with $5 \mathrm{HT}(51.1 \pm 2.7 \% ; n=22)$, DA $(50.8 \pm 2.9 \% ; n=17)$, or $5 \mathrm{HT}$ and DA compounds $(45.8 \pm 2.9 \% ; n=22)$. (C, left $)$ At the 24-h tone test, while knockout mice or knockout mice treated with 5HT or DA compounds exhibited a significant reduction in tonedependent freezing compared with wild-type mice, knockout mice treated with 5HT and DA compounds exhibited the same tonedependent freezing as wild-type mice. (Right) Histograms show the amounts of tone-dependent freezing in wild-type mice $(34.1 \pm 2.4 \%$; $n=24)$, knockout mice $(20.1 \pm 1.8 \% ; n=22)$, and knockout mice with $5 \mathrm{HT}(25.4 \pm 3.0 \% ; n=22)$, DA $(25.8 \pm 2.7 \% ; n=17)$, or $5 \mathrm{HT}$ and DA compounds $(33.2 \pm 3.9 \% ; n=22)$. $(D$, top $)$ During the elevated Y maze learning test, knockout mice and knockout mice administered i.p. with $5 \mathrm{HT}$ or DA compounds exhibited a significant reduction in the percentage of correct choices compared with wild-type mice, and knockout mice administered i.p. with 5HT and DA compounds exhibited the same percentage of correct choices as wild-type mice. (Bottom) Histograms show the percentages of correct choices in wild-type mice $(74.4 \pm 2.5 \%$; $n=20)$, knockout mice $(52.5 \pm 2.1 \% ; n=17)$, and knockout mice treated with $5 \mathrm{HT}(60.8 \pm 2.7 \% ; n=15)$, DA $(62.1 \pm 2.3 \% ; n=14)$, or $5 \mathrm{HT}$ and DA compounds $(72.2 \pm 2.9 \% ; n=19)$. Asterisks indicate $P<0.05$ (Mann-Whitney rank sum tests).

chamber of the light-dark box and made more gate crossings between the light and dark chambers compared with wild-type mice (Supplemental Fig. S8), consistent with previous studies (The Dutch-Belgian Fragile X Consortium 1994; Peier et al. 2000; Hayashi et al. 2007). Administration of $5 \mathrm{mg} / \mathrm{kg}$ BW723C 86 and $1 \mathrm{mg} / \mathrm{kg}$ MDL1 1939 or $5 \mathrm{mg} / \mathrm{kg}$ SKF81297 and $25 \mathrm{mg} / \mathrm{kg}$ SUL in Fmr1 knockout mice increased the time spent on the open arms and in the light chamber and the number of gate crossings, whereas coadministration of low-dose BW723C86 $(0.05 \mathrm{mg} / \mathrm{kg})$, MDL11939 (0.01 mg/kg), SKF81297 (0.05 $\mathrm{mg} / \mathrm{kg})$, and SUL $(0.25 \mathrm{mg} / \mathrm{kg})$ in Fmr1 knockout mice induced no significant change in these values (Supplemental Fig. S8). Together, the anxiety-like behavior measurements suggest that the low-dose 5HT and DA drug cocktail does not induce anxiety-related side effects in Fmr1 knockout mice.

To confirm that the 5HT and DA compound cocktail may rescue the impaired associative learning in Fmr1 knockout mice, we studied the performance of wild-type and Fmr 1 knockout mice in a conditional cue-dependent associative learning task using an elevated Y maze (Fig. 7A), another GluA1-dependent associative learning task (Schmitt et al. 2004, 2005). The analysis showed that wild-type mice progressively learned the task during the learning-testing sessions, but Fmr1 knockout mice failed to do so (Fig. 7D). While administration of $5 \mathrm{HT}$ or DA compounds slightly improved the learning in Fmr1 knockout mice, coadministration of the low-dose 5HT and DA compound cocktail restored the learning in knockout mice 
to a level comparable with wild-type mice (Fig. 7D). These results confirm that administration of the low-dose $5 \mathrm{HT}$ and DA compound cocktail rescues learning deficits in Fmr1 knockout mice.

We wanted to determine whether the pharmacological rescue of associative learning deficits in Fmr1 knockout mice is mediated by the enhanced $\mathrm{PI} 3 \mathrm{~K} / \mathrm{PKB}$ signalingstimulated synaptic delivery of GluA1. Thus, we administered i.p. $5 \mathrm{mg} / \mathrm{kg}$ LY 294002, an inhibitor of PI3K, or virally expressed either GluAlct-GFP or GFP alone in knockout mice that received the low-dose 5HT and DA drug cocktail (Fig. 8A). Both administration of additional
LY 294002 and viral expression of GluA1ct-GFP, but not viral expression of GFP alone, in hippocampal CA1 neurons reduced the learning-mediated freezing in Fmr1 knockout mice treated with the 5HT and DA drug cocktail to the levels comparable with control Fmr1 knockout mice (Fig. 8B,C), suggesting the involvement of PI3K signaling and synaptic GluAl delivery in the 5HT and DA drug cocktail-dependent rescue of normal learning in Fmr1 knockout mice. Similarly, administration of additional LY 294002 or viral expression of GluA1ct-GFP, but not viral expression of GFP alone, in hippocampal CA1 neurons prevented Fmr1 knockout mice treated with the
A

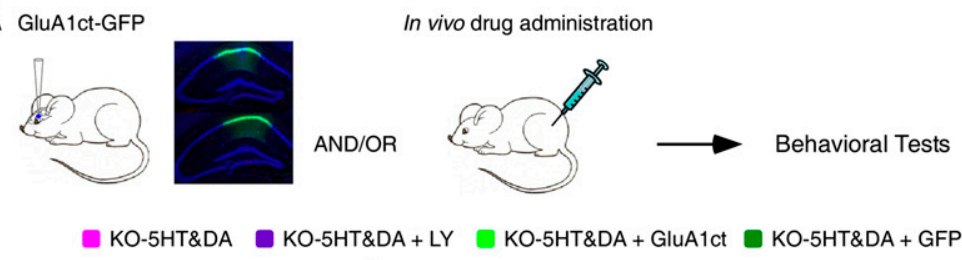

B

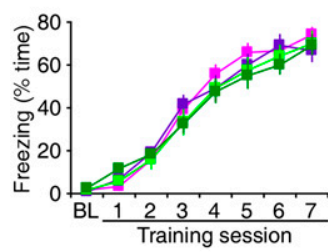

C
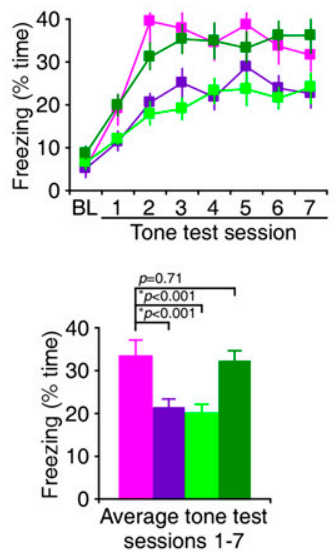

FMR1 KO

E WT

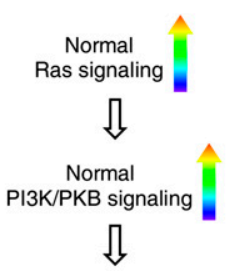

Normal

GluA1 delivery, plasticity

\& associative learning

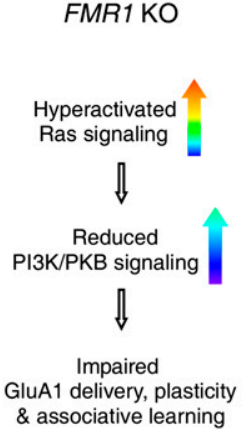

GluA1 delivery, plasticity
\& associative learning
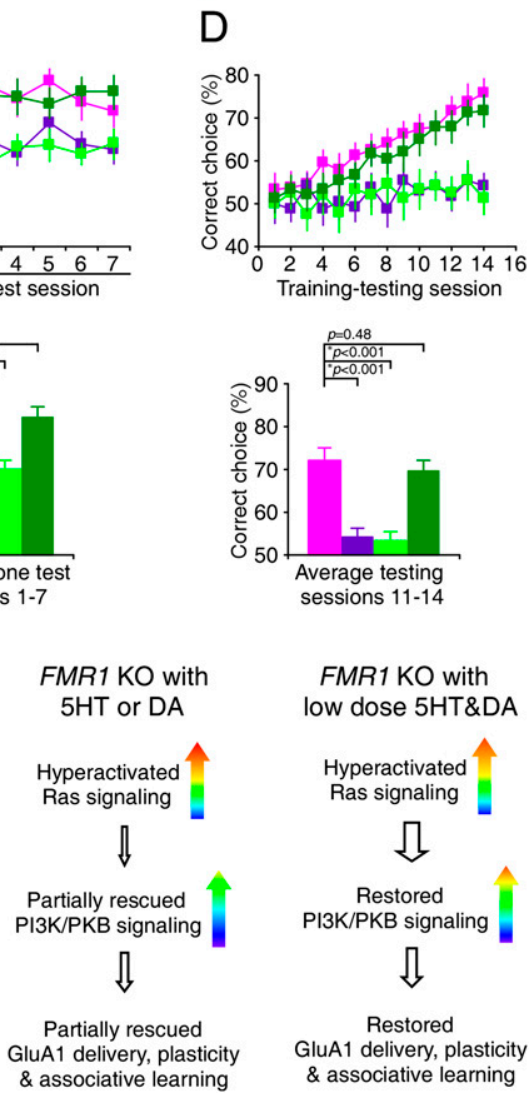

Figure 8. 5HT- and DA-dependent rescue requires PI3K signaling and synaptic GluR 1 trafficking. (A) Schematic drawing outlines the behavioral testing design. Inserted GFP fluorescence images show many CAl neurons expressing GluAlct-GFP in the neuronal marker NeuN-labeled (blue) hippocampal tissues prepared from animals after behavioral tests. $(B$, top $)$ During the trace fear conditioning, knockout (KO) mice administered i.p. with additional LY 294002 or infected with GluAlct-GFP or GFP alone in their hippocampal CA1 regions exhibited comparable amounts of freezing. (Bottom) Histograms show that amounts of freezing during conditioning in knockout mice treated with $5 \mathrm{HT}$ and DA compounds (see Fig. 7B), knockout mice treated with 5HT and DA compounds and LY 294002 (44.6 \pm $3.6 \% ; n=191$, and knockout mice treated with 5HT and DA compounds and infected with GluAlct-GFP $(42.2 \pm 3.4 \% ; n=16)$ or GFP alone $(42.1 \pm 3.2 \% ; n=18)$ in their hippocampal CA1 regions. $(C, t o p)$ At the 24-h tone test, knockout mice administered i.p. with additional LY 294002 or infected with GluAlct-GFP, but not GFP alone, in their hippocampal CA1 regions exhibited a significant reduction in tone-dependent freezing compared with wild-type (WT) mice. (Bottom) Histograms show the amounts of tone-dependent freezing in knockout mice treated with 5HT and DA compounds (see Fig. 7C), knockout mice treated with $5 \mathrm{HT}$ and DA compounds and LY 294002 (21.4 \pm $2.1 \% ; n=19$ ), and knockout mice treated with $5 \mathrm{HT}$ and DA compounds and infected with GluAlct-GFP $(19.9 \pm 2.2 \% ; n=16)$ or GFP alone $(32.1 \pm 2.5 \% ; n=18)$ in their hippocampal CA1 regions. (D, top) During the elevated Y maze learning test, knockout mice administered i.p. with additional LY 294002 or infected with GluAlct-GFP, but not GFP alone, in their hippocampal CA1 regions exhibited a significant reduction in the percentage of correct choices compared with wild-type mice, and knockout mice administered i.p. with 5HT and DA compounds exhibited the same percentage of correct choices as wild-type mice. (Bottom) Histograms show the percentages of correct choices in knockout mice treated with 5HT and DA compounds (see Fig. 7D), knockout mice treated with 5HT and DA compounds and LY $294002(54.1 \pm 2.0 \% ; n=16)$, and knockout mice treated with 5HT and DA compounds and infected with GluAlct-GFP $(53.3 \pm 2.0 \% ; n=15)$ or GFP alone $(69.6 \pm 2.7 \% ; n=18)$ in their hippocampal CA1 regions. Asterisks indicate $P<0.05$ (Mann-Whitney Rank Sum tests). (E) Model for the 5HT- and/or DA-mediated rescue of Ras-PI3K/PKB signaling, GluA1-dependent plasticity, and associative learning in Fmr1 knockout mice. Note the modest stimulating effects of 5 HT or DA compounds on Ras and $\mathrm{PI} 3 \mathrm{~K} / \mathrm{PKB}$ signaling activity and a larger effect of 5HT and DA compound cocktails on PI3K/PKB but not Ras signaling activity. 
5HT and DA drug cocktail from learning the Y maze task (Fig. 8D). Collectively, these results suggest that the 5HT and DA drug cocktail-dependent rescue of normal learning in Fmr1 knockout mice requires PI3K signaling and synaptic GluA1 delivery.

\section{Discussion}

In this study, we demonstrated that compounds activating $5 \mathrm{HT}_{2 \mathrm{~B}}$ - Rs or $\mathrm{D}_{1}$ - Rs and/or inhibiting $5 \mathrm{HT}_{2 \mathrm{~A}}-\mathrm{Rs}$ or $\mathrm{D}_{2}$ Rs modestly enhance Ras-PI3K/PKB signaling input and GluA1-dependent synaptic plasticity and partially rescue the learning deficits in Fmr1 knockout mice (Fig. 8E). Interestingly, combinations of these 5HT and DA compounds at low doses synergistically stimulate Ras-PI3K/ PKB signal transduction and GluA1-dependent synaptic plasticity to a greater degree and restore the normal associative learning in Fmr1 knockout mice without causing anxiety-related side effects (Fig. 8E). These findings suggest that properly dosed and combined FDA-approved psychoactive drugs may be used as effective treatments for the cognitive impairments associated with fragile $\mathrm{X}$ syndrome.

Synergistic effects on PI3K/PKB signaling, GluA1-dependent plasticity, and learning

Active Ras-GTP molecules can interact with their various upstream and downstream effectors to achieve specific functional signal transduction by forming immobile nanoclusters in specific subcellular membrane compartments (Murakoshi et al. 2004; Plowman et al. 2005; Tian et al. 2007). It is now clear that FMRP regulates synthesis of the proteins that are not particularly abundant and often involved in neuronal signaling regulation; many of these proteins belong to the NMDA-R-Ras-PI3K/PKB signaling interactome, including several Ras-binding partners, activators, and inactivators (Zhong et al. 1999; Brown et al. 2001; Zalfa et al. 2003; Luo et al. 2010; Darnell et al. 2011). Therefore, loss of FMRP is likely to introduce deficits in Ras trafficking and/or function at subsynaptic compartments in Fmr1 knockout mice. Indeed, our results show that synaptic Ras signal transduction is impaired even though the basal Ras activity is up-regulated in Fmr1 knockout mice. Moreover, as with previous reports (Hu et al. 2008; Gross et al. 2010; Sharma et al. 2010), we observed a small up-regulation of the basal PI3K/PKB activity in Fmr1 knockout mice, which may result directly and/or indirectly from loss of FMRP (Darnell and Klann 2013). Because PI3K/PKB activity is dynamically regulated by behavioral states and increases in awake animals (Qin et al. 2005; Hu et al. 2008; Vyazovskiy et al. 2008), we further assessed PI3K/PKB activity in awake behaving animals. Our analysis reveals that behaving Fmr1 knockout mice have reduced maximal PI3K/PKB activity compared with wild-type mice. These results together suggest that the dynamic range of PI3K/PKB signaling is compromised in Fmr1 knockout mice. The impaired Ras-PI3K/ PKB signaling dynamics may explain why $F m r 1$ knockout mice and rats with inhibited PI3K signaling share the same selective behavioral defect in associative learning (Lin et al. 2001; Chen et al. 2005; Horwood et al. 2006). In addition, the reduced Ras-PI3K/PKB signal transduction can account for several characteristics of the fragile $\mathrm{X}$ syndrome, including spine abnormality (Govek et al. 2005; Chen et al. 2010) and facial dysmorphism (O'Donnell and Warren 2002; Schubbert et al. 2007). Given the hyperactivation of Ras-PI3K/PKB signaling as the primary cause of cancer (Hanahan and Weinberg 2000), the reduced maximal PI3K/PKB signaling can also account for the reduced incidence of cancer in fragile X patients (SchultzPedersen et al. 2001; Rosales-Reynoso et al. 2010).

We report here that cocktails of 5HT and DA compounds rescue synaptic plasticity and learning in Fmr1 knockout mice via stimulating PI3K/PKB signaling dynamics and thus restoring PI3K/PKB signaling-dependent synaptic GluAl trafficking. This GluA1-dependent rescue is consistent with the findings that Fmr1 knockout mice have a predominant deficit in GluAl-dependent synaptic plasticity (Hu et al. 2008; Soden and Chen 2010), and synaptic GluAl delivery is required for associative learning (Rumpel et al. 2005; Hu et al. 2007; Matsuo et al. 2008). The GluA1-dependent rescue can also explain why Fmr1 knockout mice and fragile $\mathrm{X}$ patients exhibit a selective impairment in associative learning (Maes et al. 1994; Paradee et al. 1999; Van Dam et al. 2000; Frankland et al. 2004; Zhao et al. 2005; Hayashi et al. 2007; Lanfranchi et al. 2009), an exact phenocopy of GluA1 knockout mice (Zamanillo et al. 1999; Schmitt et al. 2004, 2005). Our data, together with previous studies, validate the notion that the dynamics of synaptic signaling (e.g., PI3K/PKB signaling) is essential for experiencedependent plasticity (e.g., GluA1-dependent plasticity) (McCormack et al. 2006), learning, and memory (Costa and Silva 2003; Thomas and Huganir 2004; Stornetta and Zhu 2011).

Many G-protein-coupled receptors, including 5HT-Rs and DA-Rs, regulate Ras-PI3K/PKB signaling (Mattingly and Macara 1996; Murga et al. 1998; Neves et al. 2002; Qin et al. 2005; Beaulieu 2012). We show here that both 5HT and DA modulators can enhance the upstream input to the Ras-PI3K/PKB signaling pathway (e.g., via potentiating upstream NMDA-R activity) (see Bekkers 1993; Qin et al. 2005) and thus partially rescue the impaired synaptic GluA1 delivery and learning deficits in Fmr1 knockout mice. Surprisingly, combinations of low doses of $5 \mathrm{HT}$ and DA modulators may synergistically stimulate PI3K/PKB signaling, rescue the impaired synaptic GluA1 delivery, and restore the normal associative learning in Fmr1 knockout mice. This synergistic effect can take place within $1 \mathrm{~d}$ after application or administration of the $5 \mathrm{HT}$ and DA compounds, which rules out the contribution from the indirect effects of $5 \mathrm{HT}$ and DA compounds (e.g., changes in mood/anxiety) that take $\geq 2$ wk to develop (Wong and Licinio 2001; David et al. 2010). Further analysis reveals that the synergistic effect is sensitive to administration of the PI3K signaling inhibitor LY 294002 or overexpression of GluAlct-GFP, suggesting a convergence of $5 \mathrm{HT}$ and DA signaling on PI3K/PKB-stimulated GluA1 trafficking. Because the low-dose 5HT and DA cocktail increases the capacity of GluA1-dependent syn- 
aptic plasticity without significantly stimulating Ras signaling, the synergistic effect is likely mediated by increasing the dynamic range of PI3K/PKB signaling, which sets the capacity of synaptic plasticity (McCormack et al. 2006). Together, these data suggest a novel synergistic mechanism of 5HT and DA modulators (Fig. 8E), which may boost signal transduction from Ras to PI3K/PKB by primarily increasing the signaling sensitivity of PI3K/PKB (cf. Premont and Gainetdinov 2007; Rajagopal et al. 2010).

\section{Clinical significance}

Fragile X, currently having no effective treatment, requires special education and psychological and medical support services and extracts an enormous, lifelong emotional, mental, and financial toll on the affected families and communities (Lee et al. 2008). Over many years of clinical tests, clinicians have observed that a few FDA-approved psychoactive drugs can modestly improve the cognitive performance of fragile $\mathrm{X}$ patients, yet these 5HT and DA modulators often cause the adverse effects related to anxiety (Hagerman et al. 2009; Tranfaglia 2011; Gross et al. 2012). In fact, ethical considerations related to frequent adverse effects, together with near infinite possible drug combinations due to unknown drug mechanisms, have so far hampered a more extensive screening and testing of effective treatments, particularly multipledrug cocktail treatments. Taking advantage of a wellestablished animal model for fragile X syndrome, we systemically examined the pharmacology and physiology (i.e., differential actions of receptor subtypes and dosages) of potentially beneficial 5HT-R-acting and DA-R-acting compounds in Fmr1 knockout mice. We show that certain 5HT and DA modulators can further stimulate Ras signaling, which provides a mechanism of action for the commonly prescribed drugs for fragile $\mathrm{X}$ patients (Fig. 8E). This mechanism may account for the clinical observations as well as our behavioral findings that administration of either 5HT or DA compounds alone can somewhat improve learning even though they often cause anxiety-related side effects in Fmr1 knockout mice. Remarkably, combinations of 5HT and DA compounds can synergistically stimulate synaptic GluAl trafficking and fully restore normal learning in Fmr1 knockout mice. In addition, these results are achieved with the half-maximal effective doses of the compounds, effectively avoiding the hyperactive side effects associated with application of high doses of 5HT or DA drugs. These results immediately suggest the exciting possibility that properly dosed FDA-approved psychoactive drug cocktails may be used as a highly efficacious treatment for fragile $\mathrm{X}$ patients. Psychoactive drugs, particularly those targeting PI3K/ PKB signaling, are commonly used to treat a number of mental and psychiatric disorders, including autism spectrum disorders, bipolar disorder, attention deficit/hyperactivity disorder, depression, and schizophrenia (Roth et al. 2004; Beaulieu 2012). Therefore, the strategy for development of a quick-to-market therapy reported here should also encourage new research on effective drug cocktail treatments for these disorders.

\section{Materials and methods}

\author{
Cultured slice preparation
}

All experiments were performed using wild-type and Fmr1 knockout male and female mice bred congenically on a C57BL/6 background (Jackson Laboratory). Cultured slices were prepared from postnatal 6- to 7-d-old mice following the previous studies (Qin et al. 2005; McCormack et al. 2006). In brief, the hippocampi were dissected out in ice-cold Hepes-buffered Hanks' solution (pH 7.35) under sterile conditions, sectioned into $400-\mu \mathrm{m}$ slices on a tissue chopper, and explanted onto a Millicell-CM membrane (0.4- $\mu \mathrm{m}$ pore size; Millipore). The membranes were then placed in $750 \mu \mathrm{L}$ of MEM culture medium containing $30 \mathrm{mM}$ HEPES, $20 \%$ heat-inactivated horse serum, $1.4 \mathrm{mM}$ glutamine, $16.25 \mathrm{mM}$ D-glucose, $5 \mathrm{mM} \mathrm{NaHCO}_{3}, 1 \mathrm{mM} \mathrm{CaCl}_{2}, 2 \mathrm{mM} \mathrm{MgSO}_{4}, 1 \mathrm{mg} / \mathrm{mL}$ insulin, $0.012 \%$ ascorbic acid ( $\mathrm{pH} 7.28$ ), and $320 \mathrm{mM}$ osmolarity. Cultured slices were maintained at $35^{\circ} \mathrm{C}$ in a humidified incubator (ambient air enriched with $5 \% \mathrm{CO}_{2}$ ).

\section{Biochemical analyses}

Biochemical analysis followed our previous studies (Qin et al. 2005; Lee et al. 2007; Hu et al. 2008). In brief, hippocampal extracts were prepared by homogenizing hippocampal CA1 regions of 14- to 29-d-old mice. To isolate the CA1 regions from intact mouse brains, hippocampi were quickly isolated and frozen with liquid $\mathrm{N}_{2}$, and CA1 regions were dissected from frozen hippocampi immediately before homogenization. The homogenizing solution contained $10 \mathrm{mM}$ HEPES, $150 \mathrm{mM} \mathrm{NaCl}, 10 \mathrm{mM}$ EDTA, 4 mM EGTA, 0.2 mM PMSF, $0.1 \mathrm{mM} \mathrm{NaPPi}, 0.5 \mathrm{mM} \mathrm{NaF}$, $1 \mathrm{mM} \mathrm{Na} \mathrm{VO}_{4}, 0.0001 \%$ chymostatin, $0.0001 \%$ leupeptin, $0.0001 \%$ antipain, $0.0001 \%$ pepstatin, and $1 \%$ Triton. Membranes were blotted with anti-phospho-p308-PKB antibody (1:2000; Cell Signaling) and anti-PKB antibody (1:1000; Cell Signaling). Active Ras was detected by affinity precipitation of Ras-GTP with the GST-linked Ras-binding domain of Raf1. The bound Ras-GTP was then eluted and Western blotted with anti-Ras antibody (1:1000; Transduction Laboratories). Western blots were quantified by chemiluminescence and densitometric scanning of the films under linear exposure conditions.

\section{Constructs and expression}

GluA1-GFP and GluA1ct-GFP constructs, made as previously described (Qin et al. 2005; Hu et al. 2008; Kielland et al. 2009), were expressed in hippocampal CA1 and cortical layer $2 / 3$ pyramidal neurons in cultured slices or intact brains using Sindbis virus. For in vitro expression, slices were infected after 7-18 $\mathrm{d}$ in vitro and then incubated on culture medium and $5 \% \mathrm{CO}_{2}$ for $15 \mathrm{~h}$ $\pm 3 \mathrm{~h}$ before experiments. For in vivo expression, postnatal 14- to 29-d-old mice, which were developmentally equivalent to the cultured slices that we used (De Simoni et al. 2003), were initially anesthetized by an i.p. injection of $10 \mathrm{mg} / \mathrm{kg}$ ketamine and $2 \mathrm{mg} / \mathrm{kg}$ xylazine. Animals were then placed in a stereotaxic frame, and one or multiple $\sim 1 \times 1$-mm holes were opened above the right or both sides of the somatosensory cortex. A glass pipette was used to make pressure injections of viral solution in the barrel cortex or hippocampal CA1 region according to stereotaxic coordinates (Qin et al. 2005; McCormack et al. 2006). For electrophysiology recordings, one injection of $\sim 100 \mathrm{~nL}$ of low-titer viral solution was made into the right barrel cortex or hippocampus to create sparse expression in the L2/3 or CA1 region. For behavioral tests, 10-12 injections of $\sim 6 \mu \mathrm{L}$ of high-titer viral solution were delivered along the entire hippocampus of both sides to achieve massive expression in about one-third of the CA1 pyramidal 
neurons (33.1\% $\pm 0.9 \% ; n=12)$ (Fig. $8 \mathrm{~A})$. After injection, animals were allowed to recover from the anesthesia and returned to their cages. To study synaptic trafficking of GluAl in vivo, expression of constructs were made when the animals were awake, which was required for synaptic delivery of GluAl (Qin et al. 2005; Hu et al. 2008). About 12-16 h after injections, some animals were prepared for acute in vitro electrophysiology experiments, while the others were prepared for behavioral tests.

\section{Drug administration}

In vitro drug application was made by maintaining slices in culture medium containing drugs from the time when they were virally infected. To achieve the steady-state drug levels, in vivo administration was made by four i.p. injections spaced by $\sim 4-6 \mathrm{~h}$, the approximate drug clearance half-time of many $5 \mathrm{HT}$ and/or DA compounds (Goodman et al. 2006). The 5HT and/or DA compound administration started $\sim 4-10 \mathrm{~h}$ before the viral injection (taking into consideration the $\sim 8 \mathrm{~h}$ required for viral expression of recombinant proteins) (Qin et al. 2005; Kielland et al. 2009) and $\sim 16-20 \mathrm{~h}$ before behavioral tests. 5HT and DA compounds were dissolved in saline, and saline alone was tested as controls, and their dosages were estimated based on the published data (PuglisiAllegra and Cabib 1988; Costall and Naylor 1995; Kennett et al. 1997; O'Dell et al. 2000; Usiello et al. 2000; Wang et al. 2008) and dose response curves (cf. Supplemental Fig. S3) and then optimized during experiments. LY 294002 was administered i.p. $0.5 \mathrm{~h}$ before behavioral tests. In all experiments except the highest concentration points of drug concentration effect curves in Supplemental Figure S3, agonists and antagonists were applied at the concentrations/doses or lower than required to maintain their specificity.

\section{Electrophysiology}

Simultaneous whole-cell recordings were obtained from nearby infected and control noninfected hippocampal CA1 or cortical layer 2/3 pyramidal neuron pairs (Qin et al. 2005; Hu et al. 2008; Jiang et al. 2013) under visual guidance using fluorescence and transmitted light illumination with two Axopatch-200B amplifiers (Axon Instruments). For cultured slices, the high-calcium and high-magnesium bath solution $\left(29^{\circ} \mathrm{C} \pm 1.5^{\circ} \mathrm{C}\right)$ containing $119 \mathrm{mM} \mathrm{NaCl}, 2.5 \mathrm{mM} \mathrm{KCl}, 4 \mathrm{mM} \mathrm{CaCl}, 4 \mathrm{mM} \mathrm{MgCl}_{2}, 26 \mathrm{mM}$ $\mathrm{NaHCO}_{3}, 1 \mathrm{mM} \mathrm{NaH} \mathrm{PO}_{4}, 11 \mathrm{mM}$ glucose, $0.1 \mathrm{mM}$ picrotoxin, and $0.002 \mathrm{mM}$ 2-chloroadenosine ( $\mathrm{pH}$ 7.4) was used to prevent epileptic activity after blocking inhibition. For acute slices, the normal bath solution $\left(33^{\circ} \mathrm{C} \pm 1.5^{\circ} \mathrm{C}\right)$ containing $125 \mathrm{mM} \mathrm{NaCl}$, $2.5 \mathrm{mM} \mathrm{KCl}, 2 \mathrm{mM} \mathrm{CaCl}_{2}, 1 \mathrm{mM} \mathrm{MgCl} 2,25 \mathrm{mM} \mathrm{NaHCO}_{3}, 1.25$ $\mathrm{mM} \mathrm{NaH} \mathrm{PO}_{4}, 11 \mathrm{mM}$ glucose, and $0.1 \mathrm{mM}$ picrotoxin $(\mathrm{pH} 7.4)$ was used. The bath solutions were gassed with $5 \% \mathrm{CO}_{2} / 95 \% \mathrm{O}_{2}$. Patch recording pipettes (3-6 M $\Omega$ ) contained $115 \mathrm{mM}$ cesium methanesulfonate, $20 \mathrm{mM} \mathrm{CsCl}, 10 \mathrm{mM}$ HEPES, $2.5 \mathrm{mM} \mathrm{MgCl}_{2}$, $4 \mathrm{mM} \mathrm{Na}{ }_{2}$ ATP, $0.4 \mathrm{mM} \mathrm{Na}_{3} \mathrm{GTP}, 10 \mathrm{mM}$ sodium phosphocreatine, $0.6 \mathrm{mM}$ EGTA, and $0.1 \mathrm{mM}$ spermine $(\mathrm{pH} 7.25)$. Synaptic responses were evoked by bipolar electrodes with single voltage pulses $(200 \mu \mathrm{sec}$, up to $20 \mathrm{~V}$ ) placed in the hippocampal stratum radiatum or cortical layer $3 \sim 300 \mu \mathrm{m}$ away from the recorded hippocampal CA1 and cortical layer $2 / 3$ pyramidal cells. Synaptic AMPA responses at $-60 \mathrm{mV}$ and $+40 \mathrm{mV}$ were averaged over 90 trials, and their ratio was used as an index of rectification. LTP was induced by a pairing protocol using 200 pulses at $2 \mathrm{~Hz}$ at $-5 \mathrm{mV}$ within $5 \mathrm{~min}$ after formation of whole-cell configuration (Qin et al. 2005; Hu et al. 2008). The responses were sampled at $0.2 \mathrm{~Hz}$ and averaged every 10 points. The amount of LTP was measured by averaging transmission $25 \mathrm{~min}$ after the LTP induction for $20 \mathrm{~min}$. Slices were incubated in a solution containing
BW723C86 and/or SKF81297 before (for at least $1 \mathrm{~h}$ ) and during LTP experiments. To minimize the effect from AMPA responses, the peak NMDA responses at $+40 \mathrm{mV}$ were measured after digital subtraction of estimated AMPA responses at $+40 \mathrm{mV}$.

\section{Behavioral analysis}

Fear conditioning tests and $\mathrm{Y}$ maze tests followed previous reports (Schmitt et al. 2004; Zhao et al. 2005; Hayashi et al. 2007; Guo et al. 2011). Briefly, the standard or trace fear conditioning was performed in an isolated shock chamber (Coulbourn Instruments). The standard fear conditioning training consisted of a 3-min exposure of mice to the conditioning box (context) followed by a foot shock ( $2 \mathrm{sec}, 0.8 \mathrm{~mA}$ ) after a preceding tone $(30 \mathrm{sec}, 3 \mathrm{kHz}, 75 \mathrm{~dB})$. The memory test was performed $24 \mathrm{~h}$ later by re-exposing the animals for $5 \mathrm{~min}$ to the conditioning context and $1 \mathrm{~h}$ later to a novel context for $3 \mathrm{~min}$ followed by a tone $(3 \mathrm{~min}, 3 \mathrm{kHz}, 75 \mathrm{~dB})$. The trace fear conditioning training consisted of a $15-\mathrm{sec}$ white noise $(3 \mathrm{kHz}, 75 \mathrm{~dB})$ conditioned stimulus (CS) and a 0.5 -sec scrambled foot shock $(0.5 \mathrm{~mA})$ unconditioned stimulus (US). Mice were acclimated for $60 \mathrm{sec}$ and then presented with seven CS-trace-US intertrial interval (ITI) trials (trace, $30 \mathrm{sec}$; ITI, $210 \mathrm{sec}$ ). One day after training, mice were acclimated for $60 \mathrm{sec}$ followed by 7 CS ITI trials (ITI, $210 \mathrm{sec}$ ) in a novel chamber to test for trace fear memory. All data were recorded using a video-based FreezeFrame system (Coulbourn Instruments). Freezing (defined as a lack of movement except for heartbeat and respiration associated with a crouching posture) and locomotor activity were analyzed offline with the Actimetrics software (Coulbourn Instruments). The additional anxiety-like behavior analysis was made using an elevated plus maze apparatus and a light-dark two-chamber box according to our previous study (Scott et al. 2011). The plus maze, with each arm measuring $6.5 \times 28 \mathrm{~cm}$, was elevated $45 \mathrm{~cm}$ from the floor in a low-light environment. Mice were placed in the center of the maze and allowed to freely explore the covered and open arms for $5 \mathrm{~min}$. The light-dark two-chamber box was made of black and white Plexiglass, with each chamber measuring $40 \times 20 \times 25 \mathrm{~cm}$. The dark chamber was not illuminated, while the light side was illuminated by bright fluorescent light. Mice were placed in the dark chamber for $2 \mathrm{~min}$. The divider separating the two chambers was then removed, and the mice were allowed to freely investigate both chambers for $10 \mathrm{~min}$. The time spent on the open arms of the elevated plus maze and the time spent in the light chamber and the number of gate crossings in the light-dark box were recorded using a video tracking system (Noldus Ethovision, Noldus Information Technology). Y maze learning tests were carried out using an elevated Y maze with one start arm and two goal arms, with each measuring $38.5 \times 9 \mathrm{~cm}$, surrounded by an opaque $13-\mathrm{cm}$-high wall (San Diego Instruments). A food well, located $3 \mathrm{~cm}$ from the end of each goal arm, was filled with $0.05 \mathrm{~mL}$ of sucrose-sweetened nonfat dry milk (12.5\%) as a reward. After 18-h food fasting with no restriction on water access, mice were first habituated to the Y maze and milk reward. Once all of the mice were running freely on the Y maze and readily consuming the milk rewards, testing began. Mice were trained and tested on a conditional learning task in which interchangeable floor inserts, either plain white or black wire mesh, covering the whole of the start arm were used as a conditional cue. The presence of the plain white insert in the start arm indicated that the $0.05-\mathrm{mL}$ milk reward was available in the right goal arm, whereas the presence of the black wire mesh insert was associated with the reward in the left arm. Mice received 14 training-testing sessions consisting of 10 trials per session with an ITI of $5 \mathrm{~min}$. Each session consisted of five trials with each of the two floor inserts and no more than 
three consecutive trials with the same floor insert, according to a pseudorandom sequence. The percentage of correct responses (entering the floor-matching goal arm and consuming the milk reward) was calculated for each session.

\section{Statistical analysis}

All results were reported as mean \pm SEM, and statistical differences of the means were determined using Wilcoxon, $\chi^{2}$ and MannWhitney rank sum nonparametric tests for paired and unpaired samples, respectively. The level of significance was set at $P<0.05$.

\section{Acknowledgments}

We thank Dr. Mark Bear, Dr. Jay Gibson, Dr. Randy Hagerman, Dr. Bong-Kiun Kaang, Dr. Gary Lynch, Dr. Michael Tranfaglia, and Dr. Brian Wiltgen for technical advice and invaluable discussions, and members of the Zhu laboratory for comments and technical assistance. This study is supported in part by the National Institutes of Health and FRAXA Research Foundation.

\section{References}

Adams CP, Brantner VV. 2010. Spending on new drug development. Health Econ 19: 130-141.

Bagni C, Greenough WT. 2005. From mRNP trafficking to spine dysmorphogenesis: The roots of fragile X syndrome. Nat Rev Neurosci 6: 376-387.

Beaulieu JM. 2012. A role for Akt and glycogen synthase kinase-3 as integrators of dopamine and serotonin neurotransmission in mental health. J Psychiatry Neurosci 37: 7-16.

Bekkers JM. 1993. Enhancement by histamine of NMDAmediated synaptic transmission in the hippocampus. Science 261: 104-106.

Bhakar AL, Dolen G, Bear MF. 2012. The pathophysiology of fragile X (and what it teaches us about synapses). Annu Rev Neurosci 35: 417-443.

Brown V, Jin P, Ceman S, Darnell JC, O'Donnell WT, Tenenbaum SA, Jin X, Feng Y, Wilkinson KD, Keene JD, et al. 2001. Microarray identification of FMRP-associated brain mRNAs and altered mRNA translational profiles in fragile $\mathrm{X}$ syndrome. Cell 107: 477-487.

Chen G, Greengard P, Yan Z. 2004. Potentiation of NMDA receptor currents by dopamine D1 receptors in prefrontal cortex. Proc Natl Acad Sci 101: 2596-2600.

Chen X, Garelick MG, Wang H, Lil V, Athos I, Storm DR. 2005. PI3 kinase signaling is required for retrieval and extinction of contextual memory. Nat Neurosci 8: 925-931.

Chen LY, Rex CS, Babayan AH, Kramar EA, Lynch G, Gall CM, Lauterborn JC. 2010. Physiological activation of synaptic Rac $>$ PAK (p-21 activated kinase) signaling is defective in a mouse model of fragile X syndrome. J Neurosci 30: 1097710984.

Costa RM, Silva AJ. 2003. Mouse models of neurofibromatosis type I: Bridging the GAP. Trends Mol Med 9: 19-23.

Costall B, Naylor RJ. 1995. Behavioural interactions between 5-hydroxytryptophan, neuroleptic agents and 5-HT receptor antagonists in modifying rodent responding to aversive situations. Br J Pharmacol 116: 2989-2999.

Darnell JC, Klann E. 2013. The translation of translational control by FMRP: Therapeutic targets for FXS. Nat Neurosci 16: $1530-1536$.

Darnell JC, Van Driesche SJ, Zhang C, Hung KY, Mele A, Fraser CE, Stone EF, Chen C, Fak JJ, Chi SW, et al. 2011. FMRP stalls ribosomal translocation on mRNAs linked to synaptic function and autism. Cell 146: 247-261.
David DJ, Wang J, Samuels BA, Rainer Q, David I, Gardier AM, Hen R. 2010. Implications of the functional integration of adult-born hippocampal neurons in anxiety-depression disorders. Neuroscientist 16: 578-591.

De Simoni A, Griesinger CB, Edwards FA. 2003. Development of rat $C A 1$ neurones in acute versus organotypic slices: Role of experience in synaptic morphology and activity. I Physiol 550: $135-147$.

Dobkin C, Rabe A, Dumas R, El Idrissi A, Haubenstock H, Brown WT. 2000. Fmrl knockout mouse has a distinctive strain-specific learning impairment. Neuroscience 100: 423429.

The Dutch-Belgian Fragile X Consortium. 1994. Fmr1 knockout mice: A model to study fragile X mental retardation. Cell 78: 23-33.

Frankland PW, Wang Y, Rosner B, Shimizu T, Balleine BW, Dykens EM, Ornitz EM, Silva AJ. 2004. Sensorimotor gating abnormalities in young males with fragile $\mathrm{X}$ syndrome and Fmr1-knockout mice. Mol Psychiatry 9: 417-425.

Gaspar P, Cases O, Maroteaux L. 2003. The developmental role of serotonin: News from mouse molecular genetics. Nat ReV Neurosci 4: 1002-1012.

Goodman LS, Gilman A, Brunton LL, Lazo JS, Parker KL. 2006. Goodman \& Gilman's the pharmacological basis of therapeutics. McGraw-Hill, New York.

Govek EE, Newey SE, Van Aelst L. 2005. The role of the Rho GTPases in neuronal development. Genes Dev 19: 1-49.

Gross C, Nakamoto M, Yao X, Chan CB, Yim SY, Ye K, Warren ST, Bassell GJ. 2010. Excess phosphoinositide 3-kinase subunit synthesis and activity as a novel therapeutic target in fragile X syndrome. J Neurosci 30: 10624-10638.

Gross C, Berry-Kravis EM, Bassell GJ. 2012. Therapeutic strategies in fragile X syndrome: Dysregulated mGluR signaling and beyond. Neuropsychopharmacology 37: 178-195.

Guo W, Allan AM, Zong R, Zhang L, Johnson EB, Schaller EG, Murthy AC, Goggin SL, Eisch AJ, Oostra BA, et al. 2011. Ablation of Fmrp in adult neural stem cells disrupts hippocampus-dependent learning. Nat Med 17: 559-565.

Gurden H, Takita M, Jay TM. 2000. Essential role of D1 but not D2 receptors in the NMDA receptor-dependent long-term potentiation at hippocampal-prefrontal cortex synapses in vivo. I Neurosci 20: RC106.

Hagerman RJ, Berry-Kravis E, Kaufmann WE, Ono MY, Tartaglia N, Lachiewicz A, Kronk R, Delahunty C, Hessl D, Visootsak $\mathrm{J}$, et al. 2009. Advances in the treatment of fragile $\mathrm{X}$ syndrome. Pediatrics 123: 378-390.

Han CJ, O'Tuathaigh CM, van Trigt L, Quinn JJ, Fanselow MS, Mongeau R, Koch C, Anderson DJ. 2003. Trace but not delay fear conditioning requires attention and the anterior cingulate cortex. Proc Natl Acad Sci 100: 13087-13092.

Hanahan D, Weinberg RA. 2000. The hallmarks of cancer. Cell 100: $57-70$.

Hayashi Y, Shi SH, Esteban JA, Piccini A, Poncer JC, Malinow R. 2000. Driving AMPA receptors into synapses by LTP and CaMKII: Requirement for GluR1 and PDZ domain interaction. Science 287: 2262-2267.

Hayashi ML, Rao BS, Seo JS, Choi HS, Dolan BM, Choi SY, Chattarji S, Tonegawa S. 2007. Inhibition of p21-activated kinase rescues symptoms of fragile $\mathrm{X}$ syndrome in mice. Proc Natl Acad Sci 104: 11489-11494.

Horwood JM, Dufour F, Laroche S, Davis S. 2006. Signalling mechanisms mediated by the phosphoinositide 3-kinase/Akt cascade in synaptic plasticity and memory in the rat. Eur $J$ Neurosci 23: 3375-3384.

Hu H, Real E, Takamiya K, Kang MG, Ledoux J, Huganir RL, Malinow R. 2007. Emotion enhances learning via norepi- 
nephrine regulation of AMPA-receptor trafficking. Cell 131: 160-173.

Hu H, Qin Y, Bochorishvili G, Zhu Y, van Aelst L, Zhu JJ. 2008. Ras signaling mechanisms underlying impaired GluR1dependent plasticity associated with fragile X syndrome. I Neurosci 28: 7847-7862.

Jacobs BL, Azmitia EC. 1992. Structure and function of the brain serotonin system. Physiol Rev 72: 165-229.

Jiang X, Wang G, Lee AJ, Stornetta RL, Zhu JJ. 2013. The organization of two new cortical interneuronal circuits. Nat Neurosci 16: 210-218.

Kennett GA, Ainsworth K, Trail B, Blackburn TP. 1997. BW 723C86, a 5-HT2B receptor agonist, causes hyperphagia and reduced grooming in rats. Neuropharmacology 36: 233-239.

Kessels HW, Malinow R. 2009. Synaptic AMPA receptor plasticity and behavior. Neuron 61: 340-350.

Kielland A, Bochorishvili G, Corson J, Zhang L, Rosin DL, Heggelund P, Zhu JJ. 2009. Activity patterns govern synapsespecific AMPA-R trafficking between deliverable and synaptic pools. Neuron 62: 84-101.

Kwon OB, Paredes D, Gonzalez CM, Neddens J, Hernandez L, Vullhorst D, Buonanno A. 2008. Neuregulin-1 regulates LTP at CA1 hippocampal synapses through activation of dopamine D4 receptors. Proc Natl Acad Sci 105: 15587-15592.

Lanfranchi S, Cornoldi C, Drigo S, Vianello R. 2009. Working memory in individuals with fragile $\mathrm{X}$ syndrome. Child Neuropsychol 15: 105-119.

Lee SH, Lim CS, Park H, Lee JA, Han JH, Kim H, Cheang YH, Lee YS, Ko HG, Jang DH, et al. 2007. Nuclear translocation of CAM-associated protein activates transcription for longterm facilitation in Aplysia. Cell 129: 801-812.

Lee LC, Harrington RA, Louie BB, Newschaffer CJ. 2008. Children with autism: Quality of life and parental concerns. I Autism Dev Disord 38: 1147-1160.

Levenga J, de Vrij FM, Oostra BA, Willemsen R. 2010. Potential therapeutic interventions for fragile $\mathrm{X}$ syndrome. Trends Mol Med 16: 516-527.

Li S, Cullen WK, Anwyl R, Rowan MJ. 2003. Dopaminedependent facilitation of LTP induction in hippocampal CA1 by exposure to spatial novelty. Nat Neurosci 6: $526-531$.

Li B, Woo RS, Mei L, Malinow R. 2007. The neuregulin-1 receptor ErbB4 controls glutamatergic synapse maturation and plasticity. Neuron 54: 583-597.

Lin CH, Yeh SH, Lu KT, Leu TH, Chang WC, Gean PW. 2001. A role for the PI-3 kinase signaling pathway in fear conditioning and synaptic plasticity in the amygdala. Neuron 31: 841-851.

Luo Y, Shan G, Guo W, Smrt RD, Johnson EB, Li X, Pfeiffer RL, Szulwach KE, Duan R, Barkho BZ, et al. 2010. Fragile $x$ mental retardation protein regulates proliferation and differentiation of adult neural stem/progenitor cells. PLoS Genet 6: e1000898.

Maes B, Fryns JP, Van Walleghem M, Van den Berghe H. 1994. Cognitive functioning and information processing of adult mentally retarded men with fragile-X syndrome. Am J Med Genet 50: 190-200.

Man HY, Wang Q, Lu WY, Ju W, Ahmadian G, Liu L, D'Souza S, Wong TP, Taghibiglou C, Lu J, et al. 2003. Activation of PI3kinase is required for AMPA receptor insertion during LTP of mEPSCs in cultured hippocampal neurons. Neuron 38: 611624.

Matsuo N, Reijmers L, Mayford M. 2008. Spine-type-specific recruitment of newly synthesized AMPA receptors with learning. Science 319: 1104-1107.

Mattingly RR, Macara IG. 1996. Phosphorylation-dependent activation of the Ras-GRF/CDC25Mm exchange factor by muscarinic receptors and G-protein $\beta \gamma$ subunits. Nature 382: 268-272.

McCormack SG, Stornetta RL, Zhu JJ. 2006. Synaptic AMPA receptor exchange maintains bidirectional plasticity. Neuron 50: $75-88$.

Meredith RM, Holmgren CD, Weidum M, Burnashev N, Mansvelder HD. 2007. Increased threshold for spike-timingdependent plasticity is caused by unreliable calcium signaling in mice lacking fragile x gene FMR1. Neuron 54: 627-638.

Murakoshi H, Ino R, Kobayashi T, Fujiwara T, Ohshima C, Yoshimura A, Kusumi A. 2004. Single-molecule imaging analysis of Ras activation in living cells. Proc Natl Acad Sci 101: 7317-7322.

Murga C, Laguinge L, Wetzker R, Cuadrado A, Gutkind JS. 1998. Activation of Akt/protein kinase B by $\mathrm{G}$ protein-coupled receptors. A role for $\alpha$ and $\beta \gamma$ subunits of heterotrimeric $G$ proteins acting through phosphatidylinositol-3-OH kinase $\gamma$. J Biol Chem 273: 19080-19085.

Myers KR, Wang G, Sheng Y, Conger KK, Casanova JE, Zhu JJ. 2012. Arf6-GEF BRAG1 regulates JNK-mediated synaptic removal of GluA1-containing AMPA receptors: A new mechanism for nonsyndromic X-linked mental disorder. J Neurosci 32: $11716-11726$.

Neves SR, Ram PT, Iyengar R. 2002. G protein pathways. Science 296: 1636-1639.

O'Dell LE, Kreifeldt MJ, George FR, Ritz MC. 2000. The role of serotonin(2) receptors in mediating cocaine-induced convulsions. Pharmacol Biochem Behav 65: 677-681.

O'Donnell WT, Warren ST. 2002. A decade of molecular studies of fragile X syndrome. Annu Rev Neurosci 25: 315-338.

Otmakhova NA, Lisman JE. 1998. D1/D5 dopamine receptors inhibit depotentiation at CA1 synapses via cAMP-dependent mechanism. J Neurosci 18: 1270-1279.

Paradee W, Melikian HE, Rasmussen DL, Kenneson A, Conn PJ, Warren ST. 1999. Fragile X mouse: Strain effects of knockout phenotype and evidence suggesting deficient amygdala function. Neuroscience 94: 185-192.

Paul SM, Mytelka DS, Dunwiddie CT, Persinger CC, Munos BH, Lindborg SR, Schacht AL. 2010. How to improve R\&D productivity: The pharmaceutical industry's grand challenge. Nat Rev Drug Discov 9: 203-214.

Peier AM, Mcllwain KL, Kenneson A, Warren ST, Paylor R, Nelson DL. 2000. (Over)correction of FMR1 deficiency with YAC transgenics: Behavioral and physical features. Hum Mol Genet 9: 1145-1159.

Plowman SJ, Muncke C, Parton RG, Hancock JF. 2005. H-ras, $\mathrm{K}$-ras, and inner plasma membrane raft proteins operate in nanoclusters with differential dependence on the actin cytoskeleton. Proc Natl Acad Sci 102: 15500-15505.

Premont RT, Gainetdinov RR. 2007. Physiological roles of $\mathrm{G}$ protein-coupled receptor kinases and arrestins. Annu Rev Physiol 69: 511-534.

Puglisi-Allegra S, Cabib S. 1988. The D2 dopamine receptor agonist LY171555 induces catalepsy in the mouse. Pharmacol Biochem Behav 30: 765-768.

Qin Y, Zhu Y, Baumgart JP, Stornetta RL, Seidenman K, Mack V, van Aelst L, Zhu JJ. 2005. State-dependent Ras signaling and AMPA receptor trafficking. Genes Dev 19: 2000-2015.

Rajagopal S, Rajagopal K, Lefkowitz RJ. 2010. Teaching old receptors new tricks: Biasing seven-transmembrane receptors. Nat Rev Drug Discov 9: 373-386.

Rosales-Reynoso MA, Ochoa-Hernandez AB, Aguilar-Lemarroy A, Jave-Suarez LF, Troyo-Sanroman R, Barros-Nunez P. 2010. Gene expression profiling identifies WNT7A as a possible candidate gene for decreased cancer risk in fragile X syndrome patients. Arch Med Res 41: 110-118.e2. 
Roth BL, Sheffler DJ, Kroeze WK. 2004. Magic shotguns versus magic bullets: Selectively non-selective drugs for mood disorders and schizophrenia. Nat Rev Drug Discov 3: 353-359.

Rumpel S, LeDoux J, Zador A, Malinow R. 2005. Postsynaptic receptor trafficking underlying a form of associative learning. Science 308: 83-88.

Schmitt WB, Arianpour R, Deacon RM, Seeburg PH, Sprengel R, Rawlins JN, Bannerman DM. 2004. The role of hippocampal glutamate receptor-A-dependent synaptic plasticity in conditional learning: The importance of spatiotemporal discontiguity. J Neurosci 24: 7277-7282.

Schmitt WB, Sprengel R, Mack V, Draft RW, Seeburg PH, Deacon RM, Rawlins JN, Bannerman DM. 2005. Restoration of spatial working memory by genetic rescue of GluR-Adeficient mice. Nat Neurosci 8: 270-272.

Schubbert S, Bollag G, Shannon K. 2007. Deregulated Ras signaling in developmental disorders: New tricks for an old dog. Curr Opin Genet Dev 17: 15-22.

Schultz-Pedersen S, Hasle H, Olsen JH, Friedrich U. 2001. Evidence of decreased risk of cancer in individuals with fragile X. Am J Med Genet 103: 226-230.

Scott MM, Marcus JN, Pettersen A, Birnbaum SG, Mochizuki T, Scammell TE, Nestler EJ, Elmquist JK, Lutter M. 2011. Hcrtr1 and 2 signaling differentially regulates depressionlike behaviors. Behav Brain Res 222: 289-294.

Seese RR, Babayan AH, Katz AM, Cox CD, Lauterborn JC, Lynch G, Gall CM. 2012. LTP induction translocates cortactin at distant synapses in wild-type but not FMR1 knock-out mice. J Neurosci 32: 7403-7413.

Shang Y, Wang H, Mercaldo V, Li X, Chen T, Zhuo M. 2009. Fragile $\mathrm{X}$ mental retardation protein is required for chemically-induced long-term potentiation of the hippocampus in adult mice. I Neurochem 111: 635-646.

Sharma A, Hoeffer CA, Takayasu Y, Miyawaki T, McBride SM, Klann E, Zukin RS. 2010. Dysregulation of mTOR signaling in fragile X syndrome. J Neurosci 30: 694-702.

Soden ME, Chen L. 2010. Fragile X protein FMRP is required for homeostatic plasticity and regulation of synaptic strength by retinoic acid. J Neurosci 30: 16910-16921.

Stornetta RL, Zhu JJ. 2011. Ras and Rap signaling in synaptic plasticity and mental disorders. Neuroscientist 17: 54-78.

Thomas GM, Huganir RL. 2004. MAPK cascade signalling and synaptic plasticity. Nat Rev Neurosci 5: 173-183.

Tian T, Harding A, Inder K, Plowman S, Parton RG, Hancock JF. 2007. Plasma membrane nanoswitches generate high-fidelity Ras signal transduction. Nat Cell Biol 9: 905-914.

Tranfaglia MR. 2011. The psychiatric presentation of fragile $\mathrm{x}$ : Evolution of the diagnosis and treatment of the psychiatric comorbidities of fragile X syndrome. Dev Neurosci 33: 337348.

Usiello A, Baik JH, Rouge-Pont F, Picetti R, Dierich A, LeMeur M, Piazza PV, Borrelli E. 2000. Distinct functions of the two isoforms of dopamine D2 receptors. Nature 408: 199-203.

Van Dam D, D'Hooge R, Hauben E, Reyniers E, Gantois I, Bakker CE, Oostra BA, Kooy RF, De Deyn PP. 2000. Spatial learning, contextual fear conditioning and conditioned emotional response in Fmrl knockout mice. Behav Brain Res 117: $127-136$.

Vyazovskiy VV, Cirelli C, Pfister-Genskow M, Faraguna U, Tononi G. 2008. Molecular and electrophysiological evidence for net synaptic potentiation in wake and depression in sleep. Nat Neurosci 11: 200-208.

Wang H, Wu LJ, Kim SS, Lee FJ, Gong B, Toyoda H, Ren M, Shang YZ, Xu H, Liu F, et al. 2008. FMRP acts as a key messenger for dopamine modulation in the forebrain. Neuron 59: 634-647.
Wong ML, Licinio J. 2001. Research and treatment approaches to depression. Nat Rev Neurosci 2: 343-351.

Zalfa F, Giorgi M, Primerano B, Moro A, Di Penta A, Reis S, Oostra B, Bagni C. 2003. The fragile X syndrome protein FMRP associates with $\mathrm{BC} 1 \mathrm{RNA}$ and regulates the translation of specific mRNAs at synapses. Cell 112: 317-327.

Zamanillo D, Sprengel R, Hvalby O, Jensen V, Burnashev N, Rozov A, Kaiser KM, Koster HJ, Borchardt T, Worley P, et al. 1999. Importance of AMPA receptors for hippocampal synaptic plasticity but not for spatial learning. Science 284: 1805-1811.

Zhao MG, Toyoda H, Ko SW, Ding HK, Wu LJ, Zhuo M. 2005. Deficits in trace fear memory and long-term potentiation in a mouse model for fragile X syndrome. J Neurosci 25: 73857392.

Zhong N, Ju W, Nelson D, Dobkin C, Brown WT. 1999. Reduced mRNA for G3BP in fragile X cells: Evidence of FMR1 gene regulation. Am J Med Genet 84: 268-271.

Zhong P, Liu W, Gu Z, Yan Z. 2008. Serotonin facilitates longterm depression induction in prefrontal cortex via p38 MAPK/ Rab5-mediated enhancement of AMPA receptor internalization. J Physiol 586: 4465-4479.

Zhu JJ. 2009. Activity level-dependent synapse-specific AMPA receptor trafficking regulates transmission kinetics. I Neurosci 29: 6320-6335. 


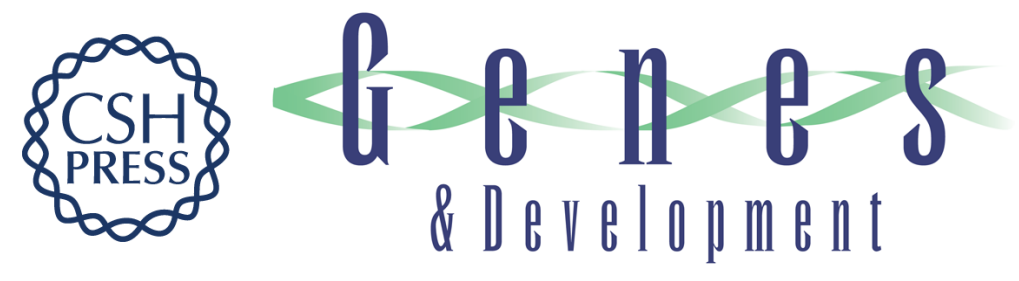

\section{Pharmacological rescue of Ras signaling, GluA1-dependent synaptic plasticity, and learning deficits in a fragile $X$ model}

Chae-Seok Lim, Elizabeth T. Hoang, Kenneth E. Viar, et al.

Genes Dev. 2014, 28:

Access the most recent version at doi:10.1101/gad.232470.113

\section{Supplemental http://genesdev.cshlp.org/content/suppl/2014/01/31/28.3.273.DC1 \\ Material}

References This article cites 94 articles, 28 of which can be accessed free at: http://genesdev.cshlp.org/content/28/3/273.full.html\#ref-list-1

Creative This article is distributed exclusively by Cold Spring Harbor Laboratory Press for the first Commons six months after the full-issue publication date (see

License http://genesdev.cshlp.org/site/misc/terms.xhtml). After six months, it is available under a Creative Commons License (Attribution-NonCommercial 3.0 Unported), as described at http://creativecommons.org/licenses/by-nc/3.0/.

Email Alerting Receive free email alerts when new articles cite this article - sign up in the box at the top Service right corner of the article or click here.

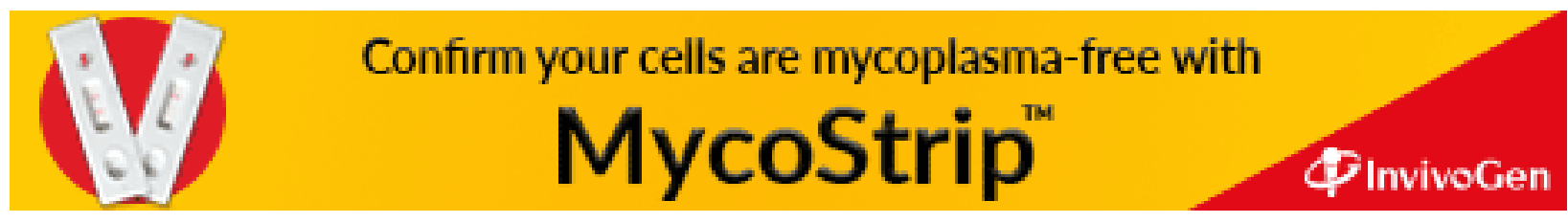

